\title{
Formation and properties of the whey protein/к-casein complexes in heated skim milk - A review
}

\author{
Laurence DONATO ${ }^{1}$, Fanny GUYOMARC' $\mathrm{H}^{2,3 *}$ \\ ${ }^{1}$ Nestlé Research Center, P.O. Box 44, 1000 Lausanne 26, Switzerland \\ 2 INRA, UMR 1253, Science et Technologie du Lait et de l'CEuf, 65 rue de St Brieuc, \\ 35000 Rennes, France \\ ${ }^{3}$ Agrocampus Ouest, UMR 1253, Science et Technologie du Lait et de l'Euf, 65 rue de St Brieuc, \\ 35000 Rennes, France
}

Received 26 May 2008 - Accepted 3rd November 2008

\begin{abstract}
The formation of complexes between whey proteins and $\kappa$-casein during heat treatment of milk dramatically affects the protein organisation in both the colloidal casein and the serum phases of milk and consequently, its technological applications. This paper reviews the composition and building interactions of these complexes and their localisation between the casein micelle and lactoserum. The currently proposed mechanisms that lead to their formation are also presented. The physico-chemical properties of these complexes, in terms of structure, size and surface properties are described and the technological means by which these properties could be controlled are discussed. Finally, the current hypotheses that explain the functional properties of these complexes in the heat-induced changes of dairy applications are reviewed, with emphasis on acid gelation of milk.
\end{abstract}

heat treatment / whey protein / $\kappa-$ casein / complex

摘要 - 热处理脱脂乳中乳清蛋白/ $\kappa$-酪蛋白复合物的形成和特性一一综述。由于热处理导 致的乳清蛋白/ $\kappa$-酪蛋白复合物的形成严重影响了酪蛋白胶体和乳清蛋白的组织状态及其应 用特性。本文综述了乳成分、复合物交互作用产生的原因、以及复合物在酪蛋白胶束和乳 清之间的定位。概述了乳清蛋白/ $\mathrm{K}$-酪蛋白复合物形成机理; 描述了复合物的结构、颗粒形 状、尺寸和表面特性等物理化学性质; 以及控制复合物特性的技术方法。最后, 阐述了热诱 导的复合物在乳品加工中的作用, 特别是对酸凝胶形成的作用。

热处理 / 乳清蛋白 / $\kappa$-酪蛋白 / 复合物

Résumé - Formation et propriétés des complexes protéines sériques/caséine $\kappa$ dans le lait écrémé traité thermiquement. Revue. La formation de complexes entre les protéines sériques et la caséine $\kappa$ au cours du traitement thermique du lait modifie profondément l'organisation des protéines dans la phase caséine micellaire et dans le lactosérum, et par conséquent ses aptitudes technologiques. Cet article fait l'état de l'art de la composition, des interactions impliquées dans les complexes et de leur localisation entre caséine micellaire et lactosérum.

\footnotetext{
*Corresponding author (通讯作者): fanny.guyomarch@rennes.inra.fr
} 
Les mécanismes actuellement proposés pour décrire la formation de ces complexes sont présentés. Les propriétés physico-chimiques des complexes, telles que leur structure, leur taille et leurs propriétés de surface, sont décrites et les moyens technologiques permettant de moduler ces propriétés sont discutés. Enfin, les hypothèses actuellement proposées pour expliquer les propriétés fonctionnelles des complexes au cours des procédés de transformation du lait sont exposées, avec une attention particulière pour la gélification acide du lait.

traitement thermique / protéine sérique / caséine $\kappa$ / complexe

\section{INTRODUCTION}

Milk proteins are commonly divided between caseins and whey proteins, corresponding, respectively, to about 80 and $20 \%$ of the total protein. Caseins are essentially composed of four different types, namely the $\kappa, \alpha_{\mathrm{s} 1}, \alpha_{\mathrm{s} 2}$ and $\beta$ caseins. In milk biological conditions, the casein molecules associate to form supramolecular assemblies named casein micelles, which are in dynamic equilibrium with the soluble phase of milk. Whey proteins have a globular structure and essentially include $\beta$-lactoglobulin, $\alpha$-lactalbumin, blood protein immunoglobulins, and Bovine Serum Albumin [100, 193]. When milk is heattreated at temperatures of $\sim 60{ }^{\circ} \mathrm{C}$ and above, the whey proteins unfold, irreversibly denature [80,148, 149, 159] and eventually aggregate through hydrophobic bonding and thiol/disulphide exchanges with themselves and with, essentially, $\kappa$-casein, leading to the so-called whey protein/ $/$-casein complexes $[70,95,135$, 171, 176].

Heat treatment is applied in many dairy processes either to enhance desirable properties of the products, such as texture and taste, or to ensure its safety and shelf-life. Heat-treated milk proteins have interesting functional properties that are widely applied in food, cosmetics or pharmacy. In the last few decades, extensive research has been dedicated to the understanding of the heat-induced aggregation of denatured whey proteins in milk or in its fractions (whey, whey protein isolates) as well as in model systems of individual proteins, especially $\beta$-lactoglobulin $[15,20,25,38,39,43$, 56,61,65,85-87,92,108,109,140,141,156, $165,179,191]$. However, the simple comparison of heat-treated whey and skim milk strongly suggests that the presence of caseins, especially $\kappa$-casein, dramatically affects the characteristics of the heat-induced protein complexes in milk $[21,51,151]$.

Since the publication of earlier reviews by Hill [84] and Sawyer [167], significant advances have been made in understanding the formation and properties of whey protein/К-casein complexes in heated milk. The present state of the art therefore aims at updating this knowledge. First, the location and composition of these complexes will be described in milk, and the proposed pathways that may yield to their formation will be discussed. The structural and physico-chemical properties of the whey protein/ $/$-casein complexes will then be described, taking their possible intrinsic variations into account. The formation of whey protein/ $\kappa$-casein complexes affects many dairy processes such as, e.g., cheesemaking and recovery of the whey protein [69], yoghurt-making [41, 123], storage of UHT milks [129] and preparation of functional ingredients. To improve these processes, technological strategies must therefore be grounded on an extensive knowledge of the properties of the whey protein/К-casein complexes. Finally, further possible prospects for research and application will be proposed. 


\section{FORMATION OF $\kappa$-CASEIN/ WHEY PROTEIN COMPLEXES IN HEATED MILK}

\subsection{Composition and building interactions of the complexes}

\subsubsection{Composition of the heat- induced protein complexes in milk}

Early studies have long demonstrated that model mixtures of isolated $\beta$-lactoglobulin and $\kappa$-casein yielded covalent complexes through thiol-disulphide exchanges on heat treatment $[46,128,195]$ that may even gel at sufficient protein concentration [47]. In skim milk or reconstituted skim milk systems, covalent complex formation between $\kappa$-casein and $\beta$-lactoglobulin has also been clearly demonstrated $[95,134,135,171,176]$ and evidence has also been presented that $\alpha$-lactalbumin is significantly involved in these complexes [33, 105, 134, 135], most likely through similar mediation of $\beta$-lactoglobulin like that reported in model systems [48]. To a minor extent, BSA, lactoferrin $[33,50,105,161]$ and $\alpha_{\mathrm{s} 2}$-casein, containing two disulphide bridges $[70,133,150]$, are also involved in these complexes via thiol/disulphide exchanges. Immunoglobulins were suspected to partially associate with the complexes through hydrophobic interactions only $[139,141]$. In serum complexes isolated from skim milk, cysteine-free $\alpha_{\mathrm{s} 1^{-}}$and $\beta$-caseins have sometimes been reported in small proportions [96] and thought to be involved in a second type of whey protein/casein heat-induced complex as the $\mathrm{pH}$ of heat treatment is increased (see also below the effect of $\mathrm{pH}$ [50]).

A molar or mass ratio of $1-5$ whey proteins to $1 \kappa$-casein, or of $0.5-3.5$ whey proteins to $1 \kappa$-casein, was, respectively, found for the serum complexes $[3,50,70,96,162]$ and for the micelle-bound complexes isolated from heated skim milk [3, 28-30,
70] (see also Sect. 2.2). Whey proteins added to skim milk are incorporated into the complexes on heating $[28,29,51,176]$ while unreacted $\kappa$-casein has been found in milk after heat treatment $[51,70,152]$. These results indicate that the whey proteins, and especially $\beta$-lactoglobulin, are the reaction-limiting proteins to the growth of the heat-induced complexes in milk.

\subsubsection{Covalent binding through thiol/disulphide interchanges}

Only recently, mass spectroscopy has been applied to skim milk and $\beta$-lactoglobulin/ $/$-casein mixtures to try to identify the intermolecular disulphide bonds that are formed on heat treatment. In all studies, Cysteine 160 (Cys 160) of $\beta$-lactoglobulin was implicated in the formation of intermolecular disulphide bridges, e.g. with $\kappa$-casein on the surface of goat's milk casein micelles [83], with $\kappa$-casein in either the micelle or serum phase of heated skim milk [116] and with $\kappa$-casein in model protein mixtures [116], as well as with other $\beta$-lactoglobulin molecules (i.e. involving other Cys than intramolecular-bound 66) in heated model protein solutions $[32,114,115,178]$. Livney and Dalgleish [114] found that Cys $119 / 121$ of $\beta$-lactoglobulin was involved in intermolecular bonds with all the other possible cysteines of both $\kappa$-casein and $\beta$-lactoglobulin. This result was in agreement with Surroca et al. [178] and with the role played by $\beta$-lactoglobulin Cys 121 in initiating complex formation, but was not confirmed by the other studies, which rather showed that Cys 160 and 66 were implicated in intermolecular disulphide bridges, possibly as a consequence of an early intramolecular thiol/disulphide exchange between Cys 121 and one of these two cysteine residues $[32,83,115,116]$. Lowe et al. [116] suggested that differences in the disulphide-bonded products across 
systems may be due to changes in the experimental conditions and/or in the structure of the $\kappa$-casein in isolated or casein micelle forms. No formation of the intermolecular bond involving $\beta$-lactoglobulin Cys 106 could be reported in heated milk [116], which suggested that it remained buried in the core of the protein on heating [114]. No obvious preference between Cys 11 and 88 of the $\kappa$-casein was reported, suggesting that both cysteines are randomly engaged in thiol/disulphide exchanges. Heat-induced disulphide bond formation in $\beta$-lactoglobulin/ $\alpha$-lactalbumin solutions have been shown to particularly involve $\alpha$-lactalbumin Cys 6, 61, 111 and 120 [115]. Livney et al. [115] noted that $\alpha$-lactalbumin seemed a good chain carrier for thiol/disulphide exchanges once activated through the initial opening of one internal disulphide bond.

\subsubsection{Hydrophobic interactions}

Analysis of the heat-induced $\kappa$-casein/whey protein complexes found in the supernatant of heated milk in native, dissociative and reducing conditions by chromatography or electrophoresis have shown that covalent disulphide intermolecular interactions are the major building bonds in the complexes, followed by hydrophobic interactions [96, 140, 141, 171]. Addition of thiol-blocking N-ethylmaleimide (NEM) to model mixtures of $\beta$-lactoglobulin and $\kappa$-casein prior to heat treatment has, however, shown that heat-induced complex formation could yet occur on the sole basis of hydrophobic interactions [128], which were proposed to come preliminary to thiol/disulphide exchanges [76, 78]. However, to the authors' knowledge, no such demonstration has been made in milk; in particular, whether or not $\kappa$-casein is involved in such non-covalent complexes is still unclear. Blockage or absence of $\beta$-lactoglobulin's free thiol group in milk systems have shown that most of the heatinduced technological changes in milk that depend on whey protein denaturation were partly reduced when thiol/disulphide exchanges were inhibited $[10,62,120]$.

\subsubsection{Electrostatic and ionic interactions}

According to studies using either reconstituted lactose-free milk or model protein mixtures, the role of ionic interactions in the building of $\beta$-lactoglobulin/ $/$-casein complexes is minor and somewhat controversial, as ionic screening by e.g. calcium, respectively promotes [176] or inhibits [45, 77] formation of complexes. Denatured $\beta$-lactoglobulin is able to chelate significant amounts of calcium on heat treatment, both in solution [75] and in skim milk [136]. The hypothesis that some calcium could be incorporated in whey protein/ $/$-casein complexes of heated milk can therefore be made. In their study, however, Parker et al. [145] observed that the addition of sodium caseinate to skim milk, or to the serum phase of skim milk, did not affect the formation of whey protein/ $/$-casein complexes, at least in the serum phase, although the concentrations of soluble calcium and phosphate were probably decreased as a consequence of their uptake by the caseinate [35]. This result indicates that calcium may not be a required component in the formation of the heat-induced (serum) complexes.

\subsection{Location of the $\kappa$-casein/whey protein complexes in milk}

Because of its consequences on the rennet coagulation properties of milk, as detailed later, location of the heatinduced complexes as bound to the surface of the casein micelle has been accepted from early studies on and largely 
investigated (e.g. $[152,158,195])$. Evidence of heat-induced disulphide linkage between whey proteins and micellar $\kappa$-casein was presented by Jang and Swaisgood [95], and Dalgleish [33] using control pore glass separation. The binding of heat-induced whey protein/К-casein complexes further accounted for the rough surface or appendages on the casein micelles of heated milk as observed by electron microscopy [97]. Because of its generally accepted predominant location on the surface of the casein micelle [88], it has been proposed that $\kappa$-casein behaved as a nucleation site for complex formation [34]. In comparison, the occurrence of $\beta$-lactoglobulin/ $\kappa$-casein complexes in the serum phase of heated skim milk has received little attention, despite early reports by, e.g., Smits and van Brouwershaven [176] or Creamer et al. [31]. Separation of the serum of heated milk using either centrifugation or renneting, and its analysis using gel electrophoresis or size-exclusion chromatography later evidenced the significant formation of whey protein/ $\kappa$-casein complexes in the serum phase of heated milk [70, $135,171,186]$. Comparison of the micellebound and serum types of complexes separated from milk at $\mathrm{pH} 6.7$ indicated that the two types of complexes had comparable sizes and compositions [31] although micelle-bound complexes contained higher proportions of $\kappa$ - and $\alpha_{\mathrm{s} 2}$-casein and less whey proteins [70].

\subsection{Proposed aggregation pathways for complex formation}

\subsubsection{Formation of primary aggregates}

The primary formation of heat-induced $\beta$-lactoglobulin aggregates [43] or of $\beta$-lactoglobulin/ $\alpha$-lactalbulin aggregates, prior to their binding to $\kappa$-casein on the surface of the casein micelle, has been proposed in skim milk [36, 37, 53, 54, 70] as well as in model protein mixtures ([79] - pathway I.A, Fig. 1). On addition of $\beta$-lactoglobulin or $\alpha$-lactalbumin to skim milk prior to heating at $70-90{ }^{\circ} \mathrm{C}$, Corredig and Dalgleish [30] further reported that the ratio between the two whey proteins as bound to the casein micelles remained constant and proposed that it reflected the composition of $\beta$-lactoglobulin/ $\alpha$-lactalbumin primary aggregates. After separation of the serum phase of milk using precipitation of the casein micelles with chymosin, Vasbinder et al. [186] found that the serum complexes only contained negligible amounts of $\kappa$-casein and further identified these complexes as whey protein aggregates. However, no such whey protein species has ever been otherwise clearly identified in milk. Observations that $\kappa$-casein, when present, readily affected heatinduced whey protein aggregation in both milk [53, 135] and model protein mixtures $[45,72,128]$ also disagree with the primary aggregation of whey protein, devoid of $\kappa$-casein (pathway I.B, Fig. 1). Euber and Brunner [55] immobilised native $\beta$-lactoglobulin on the stationary phase of a size-exclusion chromatography column, heat-treated it to activate the thiol then applied enriched $\kappa$-casein onto the column. As covalent bonding of the $\kappa$-casein onto the activated $\beta$-lactoglobulin was possible, the authors concluded that primary aggregation of denatured whey proteins was not a requisite for the formation of heat-induced whey protein/ $\kappa$-casein complexes, at least in the model system used.

\subsubsection{Partition of soluble and micelle- bound complexes: role of the casein micelle}

Various studies have shown that a positive relationship existed between the amount of denatured whey protein and 


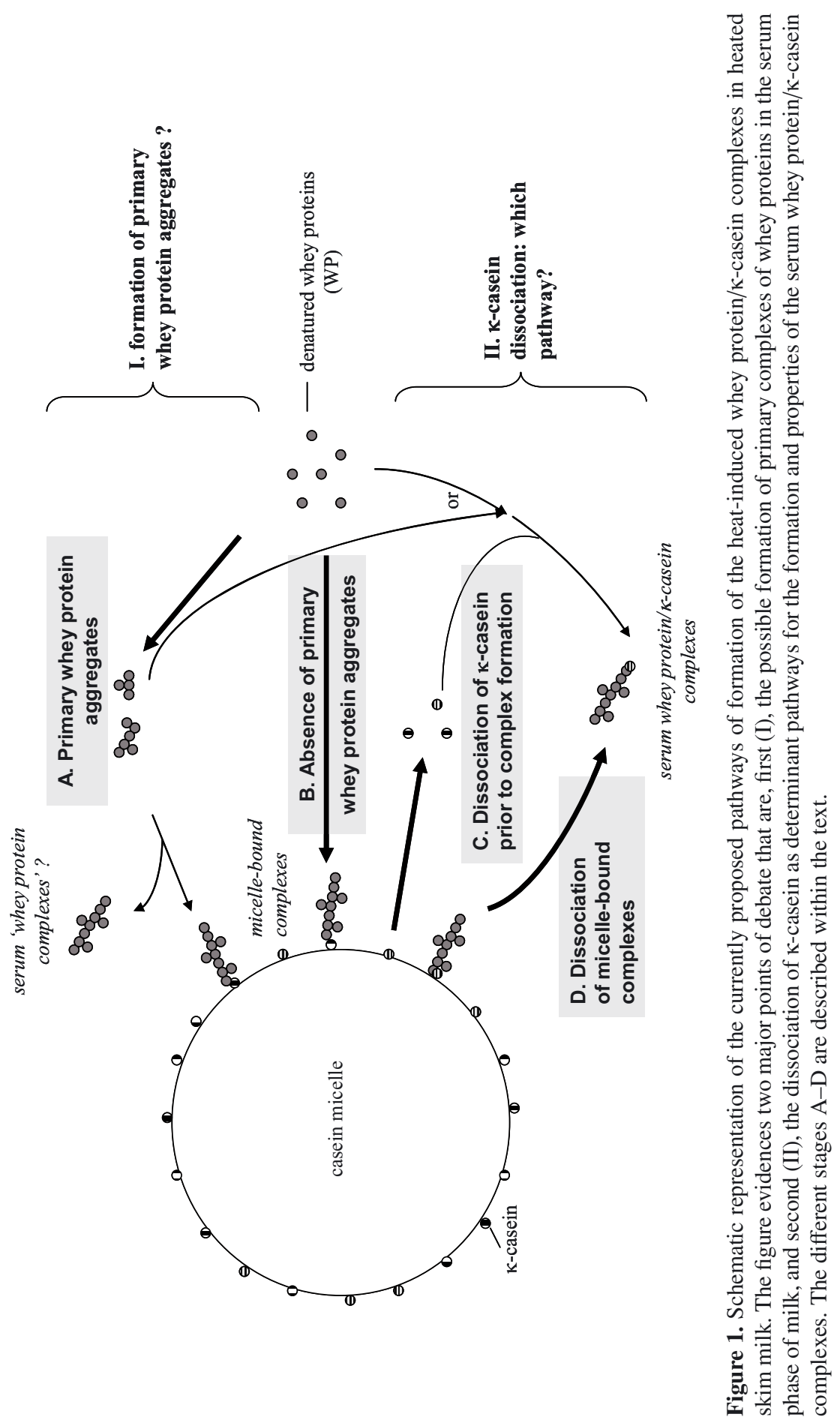


the dissociated $\kappa$-casein both found in the serum phase of milk after heat treatment $[3,5,6,130,171,173,174]$. This evidence suggests that formation of the heat-induced whey protein/ $/$-casein serum complexes is somewhat related to dissociation of the $\kappa$-casein, and the question arises as to whether the dissociation of $\kappa$-casein occurs prior to (pathway II.C, Fig. 1), or after (pathway II.D, Fig. 1), its interaction with denatured $\beta$-lactoglobulin (or with primary heat-induced whey protein aggregates, if they exist). The answer to this question is of key importance to control the role of the heat-induced complexes better in many technological applications of heated milk. If the complexes indeed result from either pathway I or II as described in Figure 1, the local interactions between $\kappa$-casein and the whey proteins may vary and the resulting serum and micelle-bound complexes may have significantly different properties and, possibly, different functional properties during the destabilisation of skim milk, e.g., during acid gelation. To date, the reported research fails to unequivocally rule out either one pathway or the other, or to determine whether both pathways occur concomitantly.

Results that support the initial dissociation of $\kappa$-casein (pathway II.C, Fig. 1) are, first, that isolated soluble $\kappa$-casein does form complexes with whey proteins when heated in the absence of casein micelles in the serum phase of milk [51] or in model conditions [72] (see also Sect. 2.1.1). In milk, $\kappa$-casein can dissociate from the casein micelle on heating, even in the absence of whey proteins $[10,174]$; the presence of both soluble $\kappa$-casein and denatured whey proteins in the serum phase of heated milk is therefore possible. Furthermore, in skim milk Anema and Li [12] reasoned that the casein micelle should repel the denatured whey protein when skim milk is heated at $\mathrm{pH}$ values away from the isoelectric $\mathrm{pH}$ values of the micelles ( 4.8). The authors then suggested that formation of a higher proportion of serum complexes at alkaline $\mathrm{pH}$ values of milk could only be possible if $\kappa$-casein first dissociated off the casein micelle. On addition of soluble $\kappa$-casein to skim milk, Anema [4] reported that less whey proteins were being attached to the surface of the casein micelle as a result of heating, as if the added $\kappa$-casein partially derouted the whey protein away from the casein micelles. Other studies by Anema and Klostermeyer [5], Anema [4] and Anema et al. [8] furthermore suggested that dissociation of the $\kappa$-casein and heat denaturation of the denatured whey protein did not seem to kinetically coincide. In particular, $\kappa$-casein dissociated at temperatures below that of denaturation of the whey proteins [5] and reached its maximum at an earlier stage than denaturation of the whey proteins $[4,8]$. On cooling, $\kappa$-casein that had not interacted with denatured whey protein in the serum phase of milk would partially re-associate with the casein micelles, as would the other caseins [5], thus explaining the high correlation between dissociation of the $\kappa$-casein and formation of serum complexes.

On the other hand, results that support the initial interaction of the whey proteins with $\kappa$-casein on the surface of the casein micelle (pathway II.D, Fig. 1) are, first, that micelle-bound complexes unequivocally exist (see Sect. 2.2) and are probably as likely to be in equilibrium with the serum phase of milk as the other components of the casein micelles (caseins and minerals). Donato et al. [51] and Parker et al. [145] who, respectively, added soluble $\kappa$-casein $\left(3 \mathrm{~g} \cdot \mathrm{kg}^{-1}\right)$ or caseinate $\left(5-10 \mathrm{~g} \cdot \mathrm{kg}^{-1}\right)$ to skim milk reported that the added $\kappa$-casein or caseinate was not involved in the formation of the serum heatinduced complexes, as long as casein micelles were present. The authors concluded that the denatured whey proteins preferably interacted with $\kappa$-casein on the surface of the casein micelle, rather than with 
dissociated $\kappa$-casein, to form the serum complexes. Despite their conflicting results, both Dalgleish and Anema's groups have reasoned that added $\kappa$-casein in soluble form should show a higher diffusion rate and higher number of collisions with the denatured whey proteins than micellebound $\kappa$-casein $[3,4,51]$. Quite likely, other important factors for successful whey protein/ $\kappa$-casein interaction are the surface charge of the $\kappa$-casein and accessibility of its disulphide bonds. The material used by each group may be quite different in these aspects, considering the purification methods involved. In their study, Donato et al. [51] proposed that $\kappa$-casein in soluble form probably bears a high density of charge and has less accessible hydrophobic sites than $\kappa$-casein, that lies in the micellar porous outer layer. The casein micelle is indeed a porous structure through which molecules such as proteins or polymers can easily diffuse $[111,163]$. Also, the dissociation of micellar $\kappa$-casein is affected by the medium conditions. At $\mathrm{pH}$ 6.7-7.1, the heat treatment of skim milk or of whey protein-free milk to which increased concentrations of whey protein were added yielded larger dissociation of the $\kappa$-casein than that found in whey protein-free milk $[10,174]$. Reciprocally, blocking or removal of $\beta$-lactoglobulin's free thiol group prior to heat treatment of milk was reported to prevent extensive dissociation of the $\kappa$-casein $[10,62]$. Using partially renneted skim milk, Renan et al. [161] furthermore showed that almost all the denatured whey proteins interacted with immobilised, hydrophobic para- $\kappa$-casein to form micelle-bound complexes, even though up to $66 \%$ of the total $\kappa$-casein had not been hydrolysed and was therefore assumed to be capable of partially dissociating upon heating into a soluble form available for interaction with denatured whey proteins in the serum phase [174]. However, this interpretation ignores the possible implications of the polymeric distribution of $\kappa$-casein on its dissociation rate after limited renneting.

The above section shows that conflicting views exist on the actual sequence of events leading to the partition of the whey protein/ $\kappa$-casein complexes between the serum and the colloidal phases of skim milk. To date, no single experimental approach has allowed conclusive evidence, most likely because of unavoidable bias on, e.g., reactivity of thiols and charge effects (when varying $\mathrm{pH}$ ), structural changes on isolation of proteins (prior to addition) or change in hydrophobicity of the $\kappa$-casein (on renneting). It is also possible that both presented sequences actually co-exist in skim milk, rendering experimental results even more confusing. Propositions that would, to some extent, restore or maintain the original conditions of skim milk would be, e.g., to cycle $\mathrm{pH}$ (to investigate reversibility of the dissociation of serum complexes), to compartment the milk using heat-proof membranes (in complement to immobilisation of either $\kappa$-casein or $\beta$-lactoglobulin), or to use the genetic toolbox in order to modify milk in situ (e.g. alter cysteine distribution on $\kappa$-casein or $\beta$-lactoglobulin, or try to vary the dissociation behaviour of $\kappa$-casein by changing its charge through the sugar moiety).

\subsection{Kinetic parameters of complex formation as a function of protein composition and temperature}

An overview of the literature on the reaction pathway leading to whey protein/ $\kappa$-casein complexes in heated milk and related kinetics shows that no or only little research has taken into account the dissociation of $\kappa$-casein and its interaction with denatured whey protein, no matter the sequence of the two events (Fig. 1). Most kinetic studies were conducted and analysed from the 
viewpoint of $\beta$-lactoglobulin, whose denaturation/aggregation kinetics were thought to govern that of all the whey proteins. Denaturation of $\beta$-lactoglobulin in milk has essentially been reported to follow 1.5-order kinetics. The corresponding Arrhenius plot shows a break that separates two linear domains, below and above $90{ }^{\circ} \mathrm{C}[2,15,38,39,140,141]$. Both the non-integer order and non-linearity of the Arrhenius plot reflect the generally accepted two-step denaturation/aggregation process of whey proteins. At temperatures of $70-90{ }^{\circ} \mathrm{C}$, the activation energy, Ea, ranges between 250 and $350 \mathrm{~kJ} \cdot \mathrm{mol}^{-1}$ depending on studies, and it is believed that denaturation is rate-limiting [42]. At $90{ }^{\circ} \mathrm{C}$ or higher temperatures, de Jong [42] calculates that the denaturation rate constant of the $\beta$-lactoglobulin dramatically increases and that the reaction becomes almost instantaneous, so that aggregation becomes the rate-limiting step. As a consequence, Ea ranges between 30 and $100 \mathrm{~kJ} \cdot \mathrm{mol}^{-1}$ at $90-150{ }^{\circ} \mathrm{C}$. In their work, Oldfield et al. [140-142] have proposed distinct kinetic parameters for the formation of intermolecular disulphide bonds, of hydrophobic interactions and for the association of the whey proteins with the casein micelles, all three reactions being part of the overall "aggregation" step mentioned in earlier studies.

Conversely, changes in the rate of $\kappa$-casein dissociation with heating time or temperature have hardly been reported (see data by $[4,6,8]$ ). As a consequence, hardly any kinetic parameter has yet been proposed for the dissociation of $\kappa$-casein, although its relevance to skim milk was acknowledged [142]. Comparison with $\beta$-lactoglobulin denaturation would, however, help position dissociation of the $\kappa$-casein relatively to complex formation between $\kappa$-casein and $\beta$-lactoglobulin (see Sect. 2.3.2). To the authors' knowledge, the only reported attempt to introduce $\kappa$-casein into a kinetic description of aggregation reactions in milk was by de Jong and van der Linden [43], who assumed that interaction of heat-aggregated $\beta$-lactoglobulin with $\kappa$-casein was one unlikely route to termination of the heatinduced complexes. They indeed calculated that the $\beta$-lactoglobulin/ $/$-casein interaction reaction involved less than $20 \%$ of the total $\beta$-lactoglobulin, a conclusion that does not comply with recent data, as described above (see Sect. 2.3.1).

\section{STRUCTURE AND PHYSICO- CHEMICAL PROPERTIES OF THE COMPLEXES}

\subsection{Size and shape}

In skim milk, heat treatment and the subsequent formation of whey protein/א-casein complexes on the surface of the casein micelle have been shown to significantly affect micelle diameter to extents that help estimate the size range of the micelle-bound complexes. Observations using transmission (TEM) or scanning electron microscopy (SEM) have, for instance, respectively, showed the formation of elongated, over 100-nmlong appendages $([82,97,132]$ - Figs. 2A and 2D) or of 20- to 100-nm-large round appendages ([97, 144] - Fig. 2C) on the casein micelles of heated skim milk. In agreement with pictures of micelle-bound complexes, SEM observation of the serum phase of heated milk shows round-shaped serum complexes of 20-50 nm ([164] - Fig. 2G) while TEM pictures show 10-30 $\times 100-200 \mathrm{~nm}$ noodle-like particles ([31, 81, 176] - Figs. 2B, 2E and 2F). TEM noodle-like particles, whose length may exceed the size of the casein micelle in both their serum and micelle-bound form, were interpreted as smaller, $\sim 25-\mathrm{nm}$ particles that artefactually associated during sample preparation [96]. In electron 


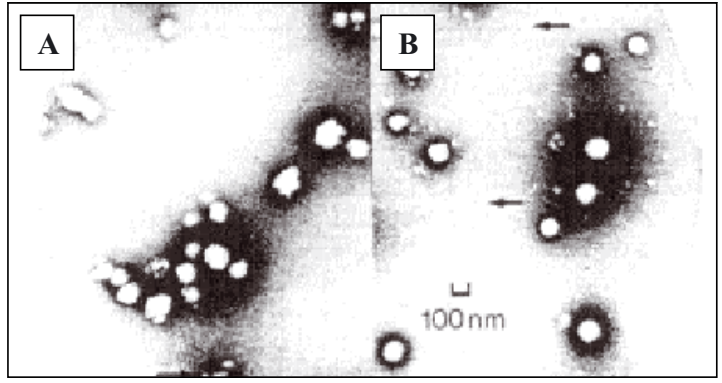

Serum and micelle-bound complexes in skim milk

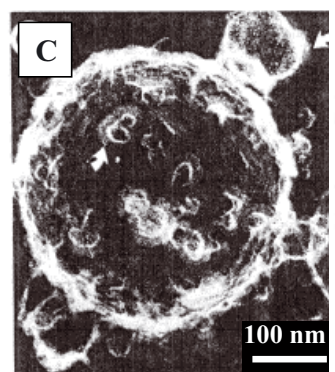

Micelle-bound complexes
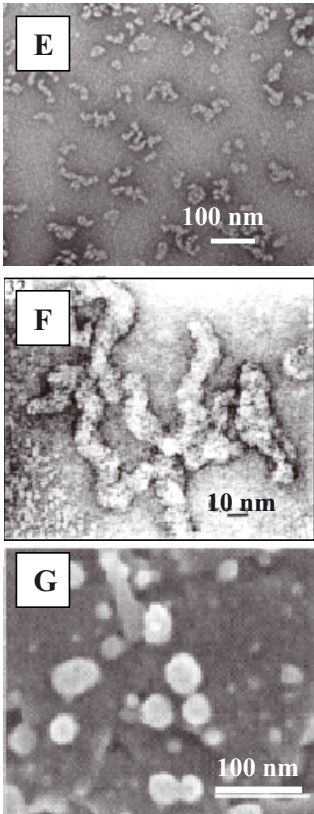

Serum complexes

Figure 2. Scanning (SEM) or Transmission Electron Micrographs (TEM) of the heat-induced whey protein/K-casein complexes found in skim milk. (A) TEM of skim milk heated at $\mathrm{pH} 6.5$ with essentially micelle-bound complexes, (B) TEM of skim milk heated at $\mathrm{pH} 6.8$ with essentially serum complexes [31]; (C) SEM or (D) TEM of one or two casein micelles with protruding micelle-bound complexes [81,97]; (E, F) TEM of isolated serum complexes [81,96]; (G) SEM of isolated serum complexes [164].

microscopy, artefacts indeed occur that would affect size such as, e.g., dehydration, projection onto a (repulsive) carbon surface that favours protein-protein interactions in TEM, coating with gold in SEM, etc. For these reasons, light scattering or improved microscopic techniques (e.g. cryo-TEM) are preferred. Application of light-scattering techniques on diluted milk generally yields smaller size values than microscopic observations. In conditions where the formation of micelle-bound complexes was favoured, studies have reported that the micellar hydrodynamic diameter $\left(D_{h}\right)$ increased by up to $40 \mathrm{~nm}$ on heating skim milk at $90{ }^{\circ} \mathrm{C}$ for 10 $30 \min [3,11,13,14,161]$, suggesting that micelle-bound complexes have a $\mathrm{D}_{\mathrm{h}}$ close to $20 \mathrm{~nm}$. In the serum phase of milk, complex sizes of 30 to $100 \mathrm{~nm}$ were reported using either light scattering or gel electrophoresis [51, 96, 164, 186], corresponding to reported molecular weight values of $\sim 3.5 \times 10^{6}$ [70] to $2 \times 10^{7} \mathrm{~g} \cdot \mathrm{mol}^{-1}$ [96]. Despite possible artefacts, Creamer et al. [31] observed that the structure of the serum whey protein/ $/$-casein complexes varied from globular to elongated particles as the $\mathrm{pH}$ of heat treatment increased, or as more $\kappa$-casein was dissociated and involved in these complexes. Similarly, unpublished results by Guyomarc'h et al. [72] showed that the whey protein/ $\kappa$-casein complexes 
formed in heated model solution turned into elongated structures as the whey protein/ $\kappa$-casein ratio decreased below 2 .

\subsection{Physico-chemical properties of the complexes}

\subsubsection{Surface charge and solubility}

Isolation of the serum complexes from skim milk using ultracentrifugation and size-exclusion chromatography $[50,70$, 171] or rennet precipitation of the casein micelle and gel electrophoresis [135, 186] have allowed their specific characterisation. Characterisation of the micelle-bound complexes, however, can still only be deduced from changes in the properties of the casein micelles on heating.

Whey protein/К-casein complexes as isolated from the serum of heated skim milk were reported to bear electronegative zeta potential values of -15 to $-20 \mathrm{mV}$ in milk ultrafiltration permeate at $25{ }^{\circ} \mathrm{C}$ at $\mathrm{pH}$ 6.7. These values compared with those of the casein micelles. The complexes precipitated in the $\mathrm{pH}$ range $3.5-5.5$ in the same medium and temperature $[74,96]$. Their apparent isoelectric $\mathrm{pH}$ value, or $\mathrm{pI}$, was found to be 4.4-4.5 and was only slightly lower than that of the casein micelles $(\sim \mathrm{pH} 4.7)$.

\subsubsection{Surface hydrophobicity}

In agreement with previous studies on heated solutions of $\beta$-lactoglobulin [160] or on ultracentrifugal fractions of heated milk [24, 91], serum heat-induced complexes bear a significantly higher surface hydrophobicity than unheated casein micelles [96]. Other results strongly suggest that the micelle-bound complexes also increase surface hydrophobicity of the heated casein micelle [74]. Anema et al. [8] and Mollé et al. [131] have evidenced that $\kappa$-casein involved in the heat-induced whey protein/א-casein complexes was cleaved by chymosin, which accounts for the little or no difference in the final amounts of caseinomacropeptide (CMP) released in heated and unheated skim milk on renneting $[8,188]$. However, despite a further increase in their surface hydrophobicity as a result of chymosin action, the serum heatinduced complexes may still be found in soluble form after renneting [131, 186]. These results indicate that strong repulsive interactions, such as electrostatic repulsion by, e.g., the C-ter end of the (residual unrenneted) $\kappa$-casein, ensure stability of the partially renneted serum complexes [161].

\subsubsection{Density}

To date, no value of the density of the heat-induced complexes is available in the literature. Assuming that the heatinduced complexes have a spherical shape, the fact that they can be separated from casein micelles using ultracentrifugation indicates that their density may be somewhat lower than that of the casein micelles $\left(1070-1250 \mathrm{~g} \cdot \mathrm{L}^{-1}[22,88]\right)$. In our centrifugal conditions, applied to heated skim milk, i.e. milk ultrafiltrate (MUF) was the solvent phase $\left(\rho_{\text {muf }} \approx 1025 \mathrm{~kg} \cdot \mathrm{m}^{-3}\right.$, $\eta_{\text {muf }} \approx 1.05 \mathrm{mPa} \cdot \mathrm{s}$ at $25^{\circ} \mathrm{C}$ ), a majority of the serum complexes $(\sim 70 \mathrm{~nm}$ average hydrodynamic diameter $\mathrm{D}_{\mathrm{h}}$ ) were pelleted at $\omega^{2} \mathrm{R}=80000 \times g$; i.e., covered $4.5 \mathrm{~cm}$ (average height of the sample in the ultracentrifugal tube) in $65 \mathrm{~min}$ $\left(\mathrm{v}=1.15 \times 10^{-5} \mathrm{~m} \cdot \mathrm{s}^{-1}\right)$. Application of Stokes' law $\mathrm{v}=\mathrm{D}_{\mathrm{h}}^{2}\left(\rho_{\text {complexes }}-\right.$ $\left.\rho_{\text {muf }}\right) \omega^{2} \mathrm{R} / 18 \eta_{\text {muf }}$ yields a first, rough estimation of $\sim 1080 \mathrm{~kg} \cdot \mathrm{m}^{-3}$ for the whey protein/К-casein complexes. As this value is within the range for casein micelles, ultracentrifugal separation of the serum complexes from casein micelles may therefore also be a consequence of their smaller size. In the future, it is suggested that voluminosity of the complexes, following the 
approach recalled in [44], is calculated to further confirm or not the above value.

Using model mixtures of whey protein isolate and casein material, Guyomarc'h et al. [72] showed that model heatinduced complexes that involved $\kappa$-casein or sodium caseinate were slightly less dense than those of similar molecular weight that only contained denatured whey proteins. If extrapolated to heated skim milk, a low density may be linked with the high water retention capacity of the heat-induced whey protein/К-casein complexes in dairy gels $[40,73,157]$.

\section{TECHNOLOGICAL FACTORS CONTROLLING PROPERTIES OF THE COMPLEXES}

This section focuses on how heattreatment conditions, including milk protein concentrations, $\mathrm{pH}$, temperature and salts, strongly affect the resulting complexes both qualitatively, through, e.g., their composition and structure, and quantitatively, through their final amount and repartition between the serum and micellar phases of skim milk.

\subsection{Composition of milk prior to heating}

The composition of the heated system affects formation of the complexes and their resulting properties at numerous levels. In skim milk, increasing the total protein concentration accelerates denaturation of the whey proteins [7]. The increase in total solid content of milk conversely increases the dissociation rate of $\kappa$-casein [6] but retards heat denaturation of the whey proteins [2] as a consequence of the protective role played by lactose and other soluble non-protein components against protein unfolding [7, 153, 154].
The initial concentrations of $\beta$-lactoglobulin and $\alpha$-lactalbumin in skim milk [28-30,37], or of whey proteins and $\kappa$-casein in model mixtures [72], will eventually affect the composition of the resulting micelle-bound and soluble complexes, as the involved proteins seem to aggregate cooperatively. Non-dairy globular proteins, e.g. from egg [57] or soy [166], may also be added to milk to successfully modify the composition of serum complexes. Various studies that used model protein mixtures also indicated that an increased concentration of $\kappa$-casein inhibited growth of heat-induced whey protein aggregates [45, 128, 135, 176]. In similar model mixtures, Guyomarc'h et al. [72] confirmed that heat-induced complexes that involved a higher proportion of $\kappa$-casein had smaller molecular weight and radius. In milk/whey blends or in micellar casein/whey protein mixtures heated in the milk solvent phase, larger micelle-bound [21] and serum complexes $[21,51,151]$ with a higher whey protein/ $\kappa$-casein ratio [70] are formed when more whey proteins and/or less casein are present. However, the effect was negligible when studying whey protein/К-casein serum complexes of heated skim milks that showed slight genetic variation in their concentrations of $\kappa$-casein and whey protein at $\mathrm{pH} 6.7$ [51]. Organisation of the $\kappa$-casein in soluble form or on the surface of the micelle also seems to bear significant importance in routing the denatured whey proteins towards formation of the micelle-bound and serum complexes $([4,51,74,145]-$ see Sect. 2.3.2).

For unknown reasons, the presence of caseins other than $\kappa$-casein may also strongly affect the heat-induced aggregation of globular proteins, including whey proteins. O'Kennedy and Mounsey [138], Zhang et al. [194], and Matsudomi et al. [127] have, for instance, reported that the addition of $\alpha_{s^{-}}$and/or $\beta$-casein 
to either whey or egg proteins inhibited extensive aggregation of the globular proteins on heat treatment. It has been proposed that the disordered caseins may exert a protective "chaperone-like" effect on unfolding globular proteins through their phosphoserine residues and/or hydrophobic surface, without formation of new heterogeneous heat-induced complexes. Would the latter scheme be general, $\kappa$-casein may therefore behave in the same way as $\alpha_{s^{-}}$or $\beta$-casein but, as it contains cysteine residues, could proceed with intermolecular thiol/disulphide exchange [72]. Other interesting studies have reported that the addition of various ligands, including denaturant species or surface-active phospholipids, to milk or whey protein solutions inhibited the heat-induced formation of model serum $[181,182]$ or micelle-bound complexes [180].

\section{2. $\mathrm{pH}$}

Of all technological factors, the effect of $\mathrm{pH}$ on the formation of the heatinduced complexes and on their distribution in milk has been widely investigated. From early studies on, it has been accepted that the proportion of heat-induced serum and micelle-bound complexes respectively increase and decrease as the $\mathrm{pH}$ of heat treatment is increased from about 6.5 to $7.5[31,102,172,173]$. Later studies have expanded this $\mathrm{pH}$ range from 5.2 [29] to 10.5 [71] with similar conclusions and have also demonstrated the sensitivity of $\mathrm{pH}$ as a factor to control the proportions of both types of complexes [3]. In skim milk heated at $80-120{ }^{\circ} \mathrm{C}$ for several minutes, $60-85 \%$ of the total whey proteins were co-located with the casein micelle at $\mathrm{pH}$ 6.4-6.5, versus $20-60 \%$ at natural $\mathrm{pH}$ values $(6.6-6.8), 10-15 \%$ at $\mathrm{pH} 6.9$ or above $[3,50,71,103,142,171,187]$ and close to $100 \%$ at pH $6.2[29,103]$. Conversely, $10-20 \%$ of the total $\kappa$-casein was found in dissociated form as a result of heat treatment at $\mathrm{pH}$ 6.3-6.5, versus 30$40 \%$ at the natural $\mathrm{pH}$ of milk and 60 $70 \%$ at $\mathrm{pH} 7.1$ or above $[3-5,8,50,130]$. These results are the direct consequence of the heat-induced reaction between denatured whey proteins and $\kappa$-casein, leading to their co-location in both the serum and the micellar phases of milk, with respective proportions that depend on the dissociation rate of $\kappa$-casein. This conclusion is in line with that of Anema [3], who reported that the amounts of nonsedimentable $\kappa$-casein and denatured whey proteins were highly correlated throughout $\mathrm{pH}$ 6.5-7.1. Although conflicting views are still opposed on its local organisation, current models have generally described the internal structure of the casein micelle as an expanded, porous network of casein molecules held together by, essentially, hydrophobic interactions and colloidal calcium phosphate (CCP [44, 89, 168, 192]). In a recent paper, Anema [4], however, reasoned that this proposition fails to account for the increased dissociation of caseins, especially $\kappa$-casein, since hydrophobic interaction and CCP should reinforce as temperature and/or $\mathrm{pH}$ are increased. As Horne [89] also pointed out, reflection on the structure of the casein micelle should probably take better account of other types of interactions, especially electrostatic, in order to explain some of its heat-induced changes. Adjusting the $\mathrm{pH}$ away from $\mathrm{pI}$, for instance, increases electrostatic repulsion between the casein molecules, while increasing temperature is expected to weaken hydrogen bonds. Aoki et al. [16] and Fox et al. [60] have also proposed that the heat-induced dissociation of caseins related to the part taken by citrate in the mineral equilibrium of calcium and phosphate, as the precipitation of calcium phosphate into irreversible forms at high temperatures would leave soluble citrate ions free to dissociate the natural cement of casein micelles. 
Of all whey proteins, it has been shown that heat denaturation of the $\beta$-lactoglobulin in model solution is affected by $\mathrm{pH}$ [159]. However, Law and Leaver [106] rather reported that the denaturation rate of most of the whey proteins in skim milk changed only moderately throughout $\mathrm{pH}$ 6-9. Despite this, significant variations exist in the resulting complexes in terms of size, shape and composition, as a function of heattreatment $\mathrm{pH}$ of skim milk. Chromatographic studies have, for instance, shown that the size and whey protein/ $/$-casein ratio of the serum complexes of skim milk decreased as the $\mathrm{pH}$ of heat treatment increased from about 6.3 to $7.3[50,162$, 164] while light-scattering analysis and protein mass distribution in milk indicated that the size of the micelle-bound complexes also decreased with increasing $\mathrm{pH}$ from 6.3 to $7.1[11,187]$. The increased amount of dissociated $\kappa$-casein as $\mathrm{pH}$ increased probably accounts for the smaller size of the serum complexes (see the effect of the whey protein/ $\kappa$-casein ratio in Sect. 4.1) but not of the micelle-bound ones. Regarding the latter, Vasbinder and de Kruif [187] have proposed that the denatured whey proteins associated with a smaller number of $\kappa$-casein sites at $\mathrm{pH}$ 6.35-6.45 than at $\mathrm{pH}$ 6.55-6.70, yielding a less homogenous coating of the casein micelle with larger complexes of a high whey protein/ $\kappa$-casein ratio. Although unreacted $\kappa$-casein has been reported in the colloidal phase of heated milk [70], the reason why there would be more of it at $\mathrm{pH}$ $6.35-6.45$ is unknown. As the $\mathrm{pH}$ of heat treatment increases, the serum complexes also involve a higher proportion of caseins other than $\kappa$-casein, possibly through formation of a different population of particles [50] and turn into noodle-like particles [31]. Changes in the $\mathrm{pH}$ of milk have important consequences on, e.g., the mineral balance between the colloidal and serum phases (e.g. [112]), activity of the thiol groups (e.g. [52]), and conformation, charge distribution and net charge of the proteins [63]; all of which being likely to affect the nature, orientation and strength of protein-protein interactions (e.g. [99]). To date, the biochemical investigation of how $\mathrm{pH}$ may control protein-protein interactions and thus direct size, shape, composition and dissociation of the whey protein/ $\kappa$-casein complexes is lacking.

\subsection{Temperature}

For a constant duration of heat treatment $(10,15$ or $30 \mathrm{~min})$, increasing the temperature of heat treatment of skim milk in the range $70-95{ }^{\circ} \mathrm{C}$ increases denaturation of whey proteins [38], aggregation into heatinduced serum and micelle-bound complexes [186] and in fine the gelation $\mathrm{pH}$ and elasticity of resulting acid gels $[123,186]$. However, for a given degree of whey protein denaturation, for which any value can be obtained through an infinite number of time-temperature loads, heating temperature in the range $70-110{ }^{\circ} \mathrm{C}$ does not dramatically affect the formation of the heat-induced whey protein/ $\kappa$-casein complexes, despite the occurrence of a welldocumented break at $80{ }^{\circ} \mathrm{C}$ or $90{ }^{\circ} \mathrm{C}$ in the Arrhenius plot for the denaturation of $\alpha$-lactalbumin and $\beta$-lactoglobulin, respectively [38]. Denaturation of the whey protein as measured by Dannenberg and Kessler [38], and Lucey et al. [123] also takes aggregation into account, albeit the resulting complexes were not positively assayed. As methods have now been developed to isolate micelle-bound or serum heat-induced whey protein/ $\kappa$-casein complexes from skim milk (see e.g. [70, 186]), it would be interesting to dedicate future research to quantitatively exploring the contribution of the complexes (size, number, etc.) to heat-induced changes in milk. 
Various authors have, however, indicated that ultra-high temperature treatments $\left(\geq 120^{\circ} \mathrm{C}\right)$ or long incubation times (>30 min) yielded changes in the properties of dairy gels made from heated milk $[41,58,101,123,146]$, possibly as a result of changes in the structure of the whey protein/ $\kappa$-casein complexes. Mottar et al. [132] proposed that micelle-bound complexes formed longer appendages in UHT-treated than in batch-heated milks, which prevented interactions between the casein micelles on acid gel formation. At ultra-high temperatures, however, other changes occur in skim milk that may also affect the properties of the resulting gels independently of the whey protein/К-casein complexes, such as casein aggregation, dephosphorylation or proteolysis [170].

\subsection{Addition of salts}

Because their presence favours attractive interactions between protein particles by screening the surface, salts and especially sodium and calcium cations have long been demonstrated to play a role in the heat-induced aggregation of whey proteins in model systems (see e.g. the review by Foegeding et al. [59]). Comparatively, little research has investigated the effects of salts on the heat-induced formation of whey protein/ $\kappa$-casein complexes in skim milk. By analogy with the behaviour of heated whey protein isolates, the fact that the concentration in soluble ions, hence the ionic strength, decreases as the $\mathrm{pH}$ of skim milk increases [112] may, however, be an explanation for the $\mathrm{pH}$-dependent changes in the final size, and possibly shape, of the heat-induced serum complexes. On decreasing the ionic strength of lactose-free skim milk model systems, Smits and van Brouwershaven [176] observed that the heat-induced association of $\beta$-lactoglobulin with the casein micelle was reduced. Whether or not serum complexes were actually formed was not indicated. The effects of calcium or sodium cations on heat-induced protein association were similar. Similarly, the increase in soluble calcium or the decrease in phosphate concentration in skim milk reduced the amount of heat-dissociated $\kappa$-casein [175], suggesting that less serum and more micelle-bound complexes may have been formed, or that less complexes were formed altogether.

Although neither the whey proteins nor $\kappa$-casein contain as many calciumbinding sites as $\alpha_{s^{-}}$or $\beta$-caseins, one has to remember that native $\alpha$-lactalbumin does contain calcium and that $\kappa$-casein has one phosphoseryl residue. Smits and van Brouwershaven [176] have varied the concentrations of calcium ions in lactosefree skim milk and reported that less calcium ions may induce association of some solubilised $\alpha_{\mathrm{s}}$ - and $\beta$-caseins with the heatinduced serum complexes, albeit the presence of dissociated caseins in the supernatant of $\mathrm{Ca}^{2+}$-depleted systems may only be a consequence of a distinct effect of the reduction of calcium ions in milk systems on the structure and equilibrium of the colloidal casein fraction [64]. However, Guyomarc'h et al. [72], who compared complex formation in model systems of whey protein isolate in the presence of either isolated $\kappa$-casein or sodium caseinate, suggested that $\alpha_{\mathrm{s}^{-}}$and $\beta$-casein do interfere with formation of model heat-induced serum complexes (see also Sect. 2.1.1). In that respect, calcium ions may be one cause for the protective role of $\alpha_{s^{-}}$and $\beta$-caseins in preventing heat-induced aggregation and precipitation of whey protein isolate in simulated milk systems [138]. It has indeed been shown that caseins, especially $\alpha_{s^{-}}$and $\beta$-caseins, e.g. in their casein micelle form, bind to calcium phosphate crystals [184] and that more calcium phosphate is being transferred to the casein micelles as the temperature increases [64, 155]. It may therefore be that, in the 
presence of caseins other than $\kappa$-casein, a large part of the soluble calcium is routed away from the denatured whey proteins, hence increasing electrostatic repulsion and promoting unfavourable conditions for heat aggregation, as already reported for model systems of whey proteins in the presence of varying ionic strength [125].

\section{FUNCTIONALITY OF THE COMPLEXES IN DAIRY TECHNOLOGY}

\subsection{Favouring acid-induced gelation of milk}

\subsubsection{Increasing gel strength and $\mathrm{pH}$ of gelation}

Because of its technological interest in yoghurt-making, the positive effect of the heat treatment of milk prior to acidification has been widely documented. Compared with unheated milk, heating milk at temperatures up to $\sim 100{ }^{\circ} \mathrm{C}$ for several minutes before acidification increases the $\mathrm{pH}$ of gelation from $\sim 4.9$ to $\sim 5.4$ [82, 120,123 ] and leads to acid gels with final higher viscosity and firmness [41, $120,123,146]$, more homogenous microstructure with higher connectivity and lower porosity of the network [98, 147] and higher whey retention capacity [40, 157], although protein rearrangements and subsequent syneresis may occur [124]. These heat-induced changes correlated well with the denaturation rate of whey proteins $[40,41,123,146]$ and formation of heat-induced whey protein/К-casein complexes $[98,120]$. These results were further supported by recent studies $[1,9,13,49,73$, $110,186,189,190]$ and have been widely reviewed [113, 117-119, 177].

\subsubsection{Proposed mechanism of interaction between casein micelles and complexes during acidification}

The respective roles of the micellebound and serum heat-induced whey protein/ $\kappa$-casein complexes in acid gelation have been investigated using the effect of the $\mathrm{pH}$ of heat treatment in the range 6.5 to 7.2 to vary the proportions of serum and micelle-bound complexes (see Sect. 4.2). On increasing the $\mathrm{pH}$ of heat treatment to 7.1 , the proportion of serum complexes is increased and higher values of the gelation $\mathrm{pH}$, faster development and higher final elasticity of the acid gels have been reported [9, 13, 103, 187], although these responses decreased on further increase in the $\mathrm{pH}$ to 7.2 [164]. Lakemond and van Vliet [103, 104] proposed that a lower proportion of micelle-bound complexes would reduce steric hindrance and thus favour early interaction between the casein micelles, hence the higher $\mathrm{pH}$ of gelation. As a consequence, the forming gel would be allowed more time for rearrangement in the course of acidification, yielding stiffer gels with larger pores and straighter strands. However, changes in the $\mathrm{pH}$ of heat treatment also induce changes in the composition, thiol reactivity and size of the heat-induced complexes that are as likely to account for these effects as the larger proportion of serum complexes at mild alkaline $\mathrm{pH}$ values. Formation of more disulphide bonds as heat-treatment $\mathrm{pH}$ is increased may, for instance, also account for higher rigidity of the resulting acid gel [103, 104].

In other studies, model milk systems at $\mathrm{pH} 6.7$ were reconstituted out of the ultracentrifugal separation of the serum and colloidal fractions of heated and unheated skim milk [49, 73, 98, 120]. Alternatively, isolated whey proteins were added to skim milk prior to, or after, heat treatment $[137,169]$. As a matter of fact, 
no clear relationship could be found when the proportions of in situ micelle-bound, in situ serum and/or added $\kappa$-casein-free whey protein serum complexes were varied in skim milk systems at $\mathrm{pH}$ 6.7. Various studies reported that acid gelation started earlier as more serum complexes were present in the system, whether the serum complexes were formed in situ [49, 73] or added to milk as whey protein complexes [137, 169]. Some studies reported the positive effect of an increased proportion of in situ or added serum complexes on the final increase in elasticity and whey retention of the acid gel [73, 137]. However, other research conversely reported that the occurrence of micellebound complexes, rather than serum ones, induced the formation of acid gels with higher final firmness [49, 120, 169] or that further heat treatment of unheated casein micelles in the presence of either in situ or added serum heat-induced complexes yielded an additional increase in the final firmness and homogeneity of the acid gel [98, 137, 169], most likely through the binding of the serum complexes to the casein micelles on heating and hence, through the increase in the proportion of micelle-bound complexes. However, in these reconstituted systems the final amount of heat-induced complexes was not constant. In a third approach, the micelle/serum partition of the heatinduced whey protein/ $\kappa$-casein complexes was modulated in situ at pH 6.7 using partially renneted casein micelles [161] and no change in the gelation behaviour of heated skim milk was reported that depended on that partition [74]. The fact that the above approaches to controlling changes in the proportions of micellebound and serum complexes do not yield converging results strongly suggests that the micelle/serum partition of complexes is not one or the only factor to account for changes in the acid gelation properties of heated skim milk. In fact, the primary factor for changes in the acid gelation behaviour of heated milk may rather be the total amount in whey protein/ $\kappa$-casein complexes, as suggested by Vasbinder et al. [186] and Donato et al. [49]. Recent studies furthermore indicated that the heatinduced serum complexes associate with the surface of the casein micelle very early in the course of acidification, i.e. turning into micelle-bound complexes before gelation starts [1, 49], although it seems that not all of them are eventually incorporated in the gel [103]. Whether or not the serum complexes also interact with each other on acidification is unclear, but when casein micelles are present they do not seem to form a separate gel [1].

Incidentally, these observations rule out the hypothesis that the heat-induced serum complexes would first gel separately as the $\mathrm{pH}$ of milk reached $\sim 5.4$ (i.e. about the $\mathrm{pI}$ of $\beta$-lactoglobulin), followed by gelation of the whey protein-coated casein micelles at $\mathrm{pH} \sim 5.1$. This hypothesis accounted for the reported two-phase formation of acid gels made from heated milk [73, 119, 123] but is not supported by the fact that pI of the serum complexes is 4.5 rather than 5.4 [96]. In fact, a similar two-phase gel formation occurs whenever acidified milk starts to gel at $\mathrm{pH}$ higher than $\sim 5.1$, independently of the presence of heat-induced complexes (e.g. [90, 121, 122]), and has been attributed to dissolution of the colloidal calcium phosphate [143].

Considering the higher surface hydrophobicity and only slightly higher pI of the whey protein/ $/$-casein complexes as compared with those of the casein micelles, Famelart et al. [57], Jean et al. [96] and Guyomarc'h et al. [74] proposed that the early onset of gelation of heated skim milk accounted for changes in the $\mathrm{pH}$ dependent attractive/repulsive balance of interactions between the milk protein particles on acidification.

Regarding gel formation and texture development, the increased surface 
hydrophobicity may help enhance connections between particles on acidification, and possibly allow some thiol/disulphide exchange on acidification [189]. The improved texture of acid gels of heated milk could also be attributed to the increased number of proteins involved in the acid network [73], hence a more connected and denser network; involving covalent disulphide bonds in the gel structure [104, 120], whereas casein acid gels are essentially based on low-energy interactions between casein particles [185]. Coating of the casein micelles by denatured whey proteins may help inhibit syneresis due to prevented fusion of the aggregated casein micelles $[98,147]$ or to the high water-binding capacity of the denatured whey proteins $[40,73,157]$.

\subsection{Preventing rennet-induced gelation of milk}

The heat treatment of skim milk, or its fractions, has long been applied as a means to recover the whey protein fraction as micelle-bound or separated complexes in the cheese curd, thus increasing both the protein and total cheese yields since the denatured whey proteins also retain water [17-19,93,94, 105, 107, 126, 196]. However, coating of the casein micelles by heatinduced whey protein/К-casein complexes affects the rennet coagulation properties of the heated milk, yielding slow-forming, soft, humid and crumbly curds.

Steric hindrance of the $\kappa$-casein, which is the substrate of chymosin, as a result of its interaction with the denatured whey proteins seems to inhibit the primary phase of renneting [26, 58, 183] although closer investigations have only reported slight or non-significant effects [8, 188]. In fact, interaction of the denatured whey proteins with the surface of the casein micelle on heating more noticeably affects the secondary phase of renneting, as it prevents micelle fusion and therefore, cohesion and syneresis of the rennet curd [126, 144, $183,188]$. As a consequence, the heating of milk as a means to increase the cheese yield is more appropriate to processes where acid coagulation is dominant over rennet action and where extensive drainage is not required, i.e. to the manufacture of lactic, fresh cheeses rather than soft or hard ones [69].

\subsection{Implications of the complexes in other processes}

Besides the largely investigated effects of heat treatment in either the acid or rennet coagulation of milk, denaturation of the whey proteins and interaction with the casein fraction have also been used to increase yields in preparation of milk protein isolates (e.g. [66]). Furthermore, heat treatment in conditions that favour the formation of small, serum complexes produces isolates with somewhat improved rehydration properties and viscosity, and modified emulsifying and foaming properties as compared with sodium caseinate or conventional milk protein isolate [67, 68]. Bohoua-Guichard et al. [23] have also reported improved emulsifying properties of model heat-induced protein complexes when both $\beta$-lactoglobulin and $\kappa$-casein are involved in the complex, rather than either one protein or the other.

On the other hand, the $\mathrm{pH}$-dependent dissociation of the $\kappa$-casein, in relation to the formation of serum, rather than micelle-bound, heat-induced whey protein/К-casein complexes has also been held responsible for the decrease in the heat stability of UHT milk as the $\mathrm{pH}$ of heating increased from 6.7 to 6.9 [172174]. At lower $\mathrm{pH}$ values where micellebound complexes are formed, it was suggested that the complexes protected the casein from heat precipitation. At $\mathrm{pH}$ values higher than 7.0, repulsive electrostatic interactions between the casein micelles were thought to take over the adverse effect 
of $\kappa$-casein depletion and to stabilise the casein micelle. McMahon [129] also proposed that extensive dissociation of the heat-induced whey protein/К-casein complexes, and subsequent aggregation, were somewhat involved in the age-gelation of UHT milk on long storage.

\section{CONCLUSION: FUTURE AND PERSPECTIVES}

Heat-induced milk protein complexes do have potential interest for current and future research aiming at optimisation of industrial dairy processes. However, one major obstacle to their application is the absence of an economically sustainable process that would allow isolation or production of the heat-induced whey protein/ $/$-casein complexes on a large scale. Only little research has been done on the formation of these complexes under other processes than heating (e.g. ultra-high pressure [27]). Better knowledge of the properties of the complexes, and of the means to control these properties, is also necessary to improve their functional potential as ingredients and to enlarge their possible application to foodstuff other than dairy gels. This includes, for instance, their intrinsic viscosity and surface properties; stability and phase diagram in various media, or flavour. Interaction of these complexes with minerals and/or other food components such as polysaccharides could also be a great asset for the future value of these complexes. Eventually, their potential nutritional properties, such as their digestibility, as well as their potential application as nanoscopic carriers of minerals or other ligands, should be examined in comparison with other milk protein fractions.

Acknowledgements: The authors wish to thank D. Dalgleish (University of Guelph, Canada) and M.-H. Famelart (UMR STLO,
Inra-Agrocampus Ouest, France) for valuable support.

\section{REFERENCES}

[1] Alexander M., Dalgleish D.G., Interactions between denatured milk serum proteins and casein micelles studied by diffusing wave spectroscopy, Langmuir 21 (2005) 1138011386.

[2] Anema S.G., Effect of milk concentration on the irreversible thermal denaturation and disulfide aggregation of $\beta$-lactoglobulin, J. Agric. Food Chem. 48 (2000) 4168-4175.

[3] Anema S.G., Role of $\kappa$-casein in the association of denatured whey proteins with casein micelles in heated reconstituted skim milk, J. Agric. Food Chem. 55 (2007) 3635-3642.

[4] Anema S.G., On heating milk, the dissociation of $\kappa$-casein from the casein micelles can precede interactions with the denatured whey proteins, J. Dairy Res. 75 (2008) 415421.

[5] Anema S.G., Klostermeyer H., Heatinduced, $\mathrm{pH}$-dependent dissociation of casein micelles on heating reconstituted skim milk at temperatures below $100{ }^{\circ} \mathrm{C}$, J. Agric. Food Chem. 45 (1997) 1108-1115.

[6] Anema S.G., Klostermeyer H., The effect of $\mathrm{pH}$ and heat treatment on the $\mathrm{K}$-casein content and the $\zeta$-potential of the particles in reconstituted skim milk, Milchwissenschaft 52 (1997) 217-222.

[7] Anema S.G., Lee S.K., Klostermeyer H., Effet of protein, non protein-soluble components, and lactose concentrations on the irreversible thermal denaturation of $\beta$-lactoglobulin and $\alpha$-lactalbumin in skim milk, J. Agric. Food Chem. 54 (2006) 7339-7348.

[8] Anema S.G., Lee S.K., Klostermeyer H., Effet of $\mathrm{pH}$ at heat treatment on the hydrolysis of $\kappa$-casein and the gelation of skim milk by chymosin, Lebensm.-Wiss. u.-Technol. 40 (2007) 99-106.

[9] Anema S.G., Lee S.K., Lowe E.K., Klostermeyer H., Rheological properties of acid gels prepared from heated $\mathrm{pH}$-adjusted skim milk, J. Agric. Food Chem. 52 (2004) 337-343.

[10] Anema S.G., Li Y., Further studies on the heat-induced, $\mathrm{pH}$-dependent dissociation of casein from the micelles in reconstituted 
skim milk, Lebensm.-Wiss. u.-Technol. 33 (2000) 335-343.

[11] Anema S.G., Li Y., Association of denatured whey proteins with casein micelles in heated reconstituted skim milk and its effect on casein micelle size, J. Dairy Res. 70 (2003) 73-83.

[12] Anema S.G., Li Y., Effect of $\mathrm{pH}$ on the association of denatured whey proteins with casein micelles in heated reconstituted skim milk, J. Agric. Food Chem. 51 (2003) 1640-1646.

[13] Anema S.G., Lowe E.K., Lee S.K., Effect of $\mathrm{pH}$ at heating on the acid-induced aggregation of casein micelles in reconstituted skim milk, Lebensm.-Wiss. u.-Technol. 37 (2004) 779-787.

[14] Anema S.G., Lowe E.K., Li Y., Effect of $\mathrm{pH}$ on the viscosity of heated reconstituted skim milk, Int. Dairy J. 14 (2004) 541-548.

[15] Anema S.G., Mc Kenna A.B., Reaction kinetics of thermal denaturation of whey proteins in heated reconstituted whole milk, J. Agric. Food Chem. 44 (1996) 422-428.

[16] Aoki T., Suzuki H., Imamura T., Formation of soluble casein in whey proteinfree milk heated at high temperature, Milchwissenschaft 29 (1974) 589-594.

[17] Banks J.M., Law A.J.R., Leaver J., Horne D.S., Sensory and functional properties of cheese: incorporation of whey proteins by $\mathrm{pH}$ manipulation and heat treatment, J. Soc. Dairy Technol. 47 (1994) 124-131.

[18] Banks J.M., Law A.J.R., Leaver J., Horne D.S., The inclusion of whey proteins in cheese - an overview, in: Emmons D.B. (Ed.), Cheese yield and factors affecting its control, IDF Seminar in Cork, International Dairy Federation, Bruxelles, Belgium, 1994, pp. 387-401.

[19] Banks J.M., Stewart G., Muir D.D., West I.G., Increasing the yield of Cheddar cheese by the acidification of milk containing heatdenatured whey protein, Milchwissenschaft 42 (1987) 212-215.

[20] Bauer R., Hansen S., Øgendal L., Detection of intermediate oligomers, important for the formation of heat aggregates of $\beta$-lactoglobulin, Int. Dairy J. 8 (1998) 105-112.

[21] Beaulieu M., Pouliot Y., Pouliot M., Thermal aggregation of whey proteins in model solutions as affected by casein/whey protein ratios, J. Food Sci. 64 (1999) 776780 .
[22] Bloomfield V.A., Morr C.V., Structure of casein micelles: physical methods, Neth. Milk Dairy J. 27 (1973) 103-120.

[23] Bohoua-Guichard L., Haque Z., Gnakri D., Kamenan A., Effect of the relative proportion of $\kappa$-casein to $\beta$-lactoglobulin on food functionality of their complex, Sci. Alim. 17 (1997) 671-678.

[24] Bonomi F., Iametti S., Real-time monitoring of the surface hydrophobicity changes associated with isothermal treatment of milk and milk protein fractions, Milchwissenschaft 46 (1991) 71-74.

[25] Boye J.I., Alli I., Ismail A.A., Effects of physicochemical factors on the secondary structure of $\beta$-lactoglobulin, J. Dairy Res. 63 (1996) 97-109.

[26] Calvo M.M., Law A.J.R., Leaver J., Heatinduced interactions between serum albumin, immunoglobulin, and $\kappa$-casein inhibit the primary phase of renneting, J. Agric. Food Chem. 43 (1995) 2823-2827.

[27] Considine T., Patel H.A., Anema S.G., Singh H., Creamer L.K., Interactions of milk proteins during heat and high hydrostatic pressure treatments - A review, Innovative Food Sci. Emerging Technol. 8 (2007) 1-23.

[28] Corredig M., Dalgleish D.G., The binding of $\alpha$-lactalbumin and $\beta$-lactoglobulin to casein micelles in milk treated by different heating systems, Milchwissenschaft 51 (1996) 123-126.

[29] Corredig M., Dalgleish D.G., Effect of temperature and $\mathrm{pH}$ on the interactions of whey proteins with casein micelles in skim milk, Food Res. Int. 29 (1996) 49-55.

[30] Corredig M., Dalgleish D.G., The mechanisms of the heat-induced interaction of whey proteins with casein micelles in milk, Int. Dairy J. 9 (1999) 233-236.

[31] Creamer L.K., Berry G.P., Matheson A.R., The effect of $\mathrm{pH}$ on protein aggregation in heated skim milk, N. Z. J. Dairy Sci. Technol. 13 (1978) 9-15.

[32] Creamer L.K., Bienvenue A., Nilsson H., Paulsson M., van Wanroij M., Lowe E.K., Anema S.G., Boland M.J., Jiménez-Flores R., Heat-induced redistribution of disulfide bonds in milk proteins. 1. Bovine $\beta$-lactoglobulin, J. Agric. Food Chem. 52 (2004) 7660-7668.

[33] Dalgleish D.G., Denaturation and aggregation of serum proteins and caseins in heated milk, J. Agric. Food Chem. 38 (1990) 1996-1999. 
[34] Dalgleish D.G., The effect of denaturation of $\beta$-lactoglobulin on renneting - a quantitative study, Milchwissenschaft 45 (1990) 491-494.

[35] Dalgleish D.G., Minéraux et propriétés fonctionnelles des caséines et caséinates, in: Gaucheron F. (Ed.), Minéraux et produits laitiers, Tec \& Doc Lavoisier, Paris, 2004, pp. 323-342.

[36] Dalgleish D.G., Senaratne V., François S., Interaction between $\alpha$-lactalbumin and $\beta$-lactoglobulin in the early stages of heat denaturation, J. Agric. Food Chem. 45 (1997) 3459-3464.

[37] Dalgleish D.G., Van Mourik L., Corredig M., Heat-induced interaction of whey proteins and casein micelles with different concentrations of $\alpha$-lactalbumin and $\beta$-lactoglobulin, J. Agric. Food Chem. 45 (1997) 4806-4813.

[38] Dannenberg F., Kessler H.-G., Reaction kinetics of the denaturation of whey proteins in milk, J. Food Sci. (1988) 259-263.

[39] Dannenberg F., Kessler H.-G., Thermodynamic approach to kinetics of $\beta$-lactoglobulin denaturation in heated skim milk and sweet whey, Milchwissenschaft 43 (1988) 139-142.

[40] Dannenberg F., Kessler H.-G., Effect of denaturation of $\beta$-lactoglobulin on texture properties of set-style nonfat yoghurt. 1 . Syneresis, Milchwissenschaft 43 (1988) 632-635.

[41] Dannenberg F., Kessler H.-G., Effect of denaturation of $\beta$-lactoglobulin on texture properties of set-style nonfat yoghurt. 2. Firmness and flow properties, Milchwissenschaft 43 (1988) 700-705.

[42] De Jong P., Two-stage reaction model for the denaturation of $\beta$-lactoglobulin in milk, in: de Jong P. (Ed.), Modelling and Optimization of Thermal Treatments in the Dairy Industry, 1996, pp. 17-33.

[43] De Jong P., van der Linden H.J.L.J., Polymerization model for prediction of heat-induced protein denaturation and viscosity changes in milk., J. Agric. Food Chem. 46 (1998) 2136-2142.

[44] De Kruif C.G., Holt C., Casein micelle structure, functions and interactions, in: Fox P.F., Mc Sweeney P.L.H. (Eds.), Advances Dairy Chemistry, Volume 1, Part A, Kluwer Academic/Plenum Publishers, New York, 2003, pp. 233276.
[45] Doi H., Ibuki F., Kanamori M., Effect of carbohydrate moiety of $\kappa$-casein on the complex formation with $\beta$-lactoglobulin, Agric. Biol. Chem. 45 (1981) 2351-2353.

[46] Doi H., Ideno S., Ibuki F., Kanamori M., Participation of the hydrophobic bond in complex formation between $\kappa$-casein and $\beta$-lactoglobulin, Agric. Biol. Chem. 47 (1983) 407-409.

[47] Doi H., Ideno S., Kuo F.H., Ibuki F., Kanamori M., Gelation of the complex between $\kappa$-casein and $\beta$-lactoglobulin, J. Nutr. Sci. Vitaminol. 29 (1983) 679-689.

[48] Doi H., Tokuyama T., Kuo F.H., Ibuki F., Kanamori M., Heat-induced complex formation between $\kappa$-casein and $\alpha$-lactalbumin, Agric. Biol. Chem. 47 (1983) 2817-2824.

[49] Donato L., Alexander M., Dalgleish D.G., Effects of serum protein composition and reactivity of the casein micellar surface on particle interactions during acid gelation of heated and unheated milks, J. Agric. Food Chem. 55 (2007) 4160-4168.

[50] Donato L., Dalgleish D.G., Effect of the $\mathrm{pH}$ of heating on the qualitative and quantitative compositions of the sera of reconstituted skim milks and on the mechanisms of formation of soluble aggregates, J. Agric. Food Chem. 54 (2006) 7804-7811.

[51] Donato L., Guyomarc'h F., Amiot S., Dalgleish D.G., Formation of whey protein/ $\kappa$-casein complexes in heated milk: preferential reaction of whey protein with $\kappa$-casein in the casein micelles, Int. Dairy J. 17 (2007) 1161-1167.

[52] Dunnill P., Green D.W., Sulphydryl groups and the $N / R$ conformational change in $\beta$-lactoglobulin, J. Mol. Biol. 15 (1965) 147-151.

[53] Elfagm A.A., Wheelock J.V., Effect of heat on $\alpha$-lactalbumin and $\beta$-lactoglobulin in bovine milk, J. Dairy Res. 44 (1977) 367371.

[54] Elfagm A.A., Wheelock J.V., Heat interaction between $\alpha$-lactalbumin, $\beta$-lactoglobulin and casein in bovine milk, J. Dairy Sci. 61 (1978) 159-163.

[55] Euber J.R., Brunner J.R., Interaction of $\kappa$-casein with immobilized $\beta$-lactoglobulin, J. Dairy Sci. 65 (1982) 2384-2387.

[56] Euston S.R., Ur-Rehman S., Costello G., Denaturation and aggregation of $\beta$-lactoglobulin - A preliminary molecular dynamics study, Food Hydrocoll. 21 (2007) 1081-1091. 
[57] Famelart M.-H., Tomazewski J., Piot M., Pezennec S., Comprehensive study of acid gelation of heated milk with model protein systems, Int. Dairy J. (2004) 313-321.

[58] Ferron-Baumy C., Maubois J.-L., Garric G., Quiblier J.-P., Coagulation présure du lait et des rétentats d'ultrafiltration. Effets de divers traitements thermiques, Lait 71 (1991) 423-434.

[59] Foegeding E.A., Davis J.P., Doucet D., Mc Guffey M.K., Advances in modifying and understanding whey protein functionality, Trends Food Sci. Technol. 13 (2002) 151-159.

[60] Fox K.K., Harper M.K., Holsinger V.H., Pallansch M.J., Effects of high-heat treatment on the stability of calcium caseinate aggregates in milk, J. Dairy Sci. 50 (1967) $443-450$.

[61] Galani D., Owusu-Apenten R.K., Heatinduced denaturation and aggregation of $\beta$-lactoglobulin: kinetics of formation of hydrophobic and disulfide-linked aggregates, Int. J. Food Sci. Technol. 34 (1999) 467-476.

[62] Gallagher D.P., Mulvihill D.M., Heat stability and renneting characteristics of milk systems containing bovine casein micelles and porcine or bovine $\beta$-lactoglobulin, Int. Dairy J. 7 (1997) 221-228.

[63] Gaucheron F., Interactions caséinescations, in: Gaucheron F. (Ed.), Minéraux et Produits Laitiers, Tec \& Doc Lavoisier, Paris, 2004, pp. 81-112.

[64] Gaucheron F., Le Graët Y., Schuck P., Équilibres minéraux et conditions physicochimiques, in: Gaucheron F. (Ed.), Minéraux et Produits Laitiers, Tec \& Doc Lavoisier, Paris, 2004, pp. 219-280.

[65] Gimel J.-C., Durand D., Nicolai T., Structure and distribution of aggregates formed after heat-induced denaturation of globular proteins, Macromolecules 27 (1994) 583-589.

[66] Grufferty M.B., Mulvihill D.M., Proteins recovered from milks heated at alkaline $\mathrm{pH}$ values, J. Soc. Dairy Technol. 40 (1987) 82-85.

[67] Grufferty M.B., Mulvihill D.M., Hydration related properties of protein isolates prepared from heated milks, J. Soc. Dairy Technol. 43 (1990) 99-103.

[68] Grufferty M.B., Mulvihill D.M., Emulsifying and foaming properties of protein isolates prepared from heated milks, J. Soc. Dairy Technol. 44 (1991) 13-19.
[69] Guyomarc'h F., Formation of heat-induced protein aggregates in milk as a means to recover the whey protein fraction in cheese manufacture, and interest of heat-treating milk at alkaline $\mathrm{pH}$ values in order to keep its rennet coagulation properties. A review, Lait 86 (2006) 1-20.

[70] Guyomarc'h F., Law A.J.R., Dalgleish D.G., Formation of soluble and micellebound protein aggregates in heated milk, J. Agric. Food Chem. 51 (2003) 4652-4660.

[71] Guyomarc'h F., Mahieux O., Renan M., Chatriot M., Gamerre V., Famelart M.-H., Changes in the acid gelation of skim milk as affected by heat-treatment and alkaline pH conditions, Lait 87 (2007) 119-137.

[72] Guyomarc'h F., Nono M., Nicolai T., Durand D., Heat induced aggregation of whey proteins in the presence of $\kappa$-casein or sodium caseinate, Food Hydrocoll. doi: 10.1016/j.foodhyd.2008.07.001.

[73] Guyomarc'h F., Quéguiner C., Law A.J.R., Horne D.S., Dalgleish D.G., Role of the soluble and micelle-bound heat-induced protein aggregates on network formation in acid skim milk gels, J. Agric. Food Chem. 51 (2003) 7743-7750.

[74] Guyomarc'h F., Renan M., Chatriot M., Gamerre V., Famelart M.-H., Acid gelation properties of heated skim milk as a result of enzymatically induced changes in the micelle/serum distribution of the whey protein/א-casein aggregates, J. Agric. Food Chem. 55 (2007) 10986-10993.

[75] Halbert C., O'Kennedy B.T., Hallihan A., Kelly P.M., Stabilisation of calcium phosphate using denatured whey proteins, Milchwissenschaft 55 (2000) 386-389.

[76] Haque Z., Kinsella J.E., Heat-induced changes in the hydrophobicity of kappacasein and $\beta$-lactoglobulin, Agric. Biol. Chem. 51 (1987) 2245-2247.

[77] Haque Z., Kinsella J.E., Interaction between $\kappa$-casein and $\beta$-lactoglobulin: effect of calcium, Agric. Biol. Chem. 51 (1987) 1997-1998.

[78] Haque Z., Kinsella J.E., Interaction between heated $\kappa$-casein and $\beta$-lactoglobulin : predominance of hydrophobic interaction in the initial stages of complex formation, J. Dairy Res. 55 (1988) 67-80.

[79] Haque Z., Kristjansson M.M., Kinsella J.E., Interaction between $\kappa$-casein and $\beta$-lactoglobulin: possible mechanism, J. Agric. Food Chem. 35 (1987) 644-649. 
[80] Havea P., Singh H., Creamer L.K., Campanella O.H., Electrophoretic characterization of the protein products formed during heat treatment of whey protein concentrate solutions, J. Dairy Res. 65 (1998) 79-91.

[81] Heertje I., Structure and function of food products: a review, Food Struct. 12 (1993) 343-364.

[82] Heertje I., Visser J., Smits P., Structure formation in acid milk gels, Food Microstruct. 4 (1985) 267-277.

[83] Henry H., Mollé D., Morgan F., Fauquant J., Bouhallab S., Heat-induced covalent complex between casein micelles and $\beta$-lactoglobulin from goat's milk: identification of an involved disulfide bond, J. Agric. Food Chem. 50 (2002) 185-191.

[84] Hill A.R., The $\beta$-lactoglobulin- $\kappa$-casein complex, Can. Inst. Food Sci. Technol. J. 22 (1989) 120-123.

[85] Hoffmann M.A.M., Sala G., Olieman C., De Kruif K.G., Molecular mass distributions of heat-induced beta-lactoglobulin aggregates, J. Agric. Food Chem. 45 (1997) 2949-2957.

[86] Hoffmann M.A.M., van Mil P.J.J.M., Heatinduced aggregation of beta-lactoglobulin: role of the free thiol group and disulfide bonds, J. Agric. Food Chem. 45 (1997) 2942-2948.

[87] Hoffmann M.A.M., van Mil P.J.J.M., Heatinduced aggregation of beta-lactoglobulin as a function of $\mathrm{pH}$, J. Agric. Food Chem. 47 (1999) 1898-1905.

[88] Holt C., Horne D.S., The hairy casein micelle: evolution of the concept and its implications for dairy technology, Neth. Milk Dairy J. 50 (1996) 85-111.

[89] Horne D.S., Casein interactions: casting light on the black boxes, the structure in dairy products, Int. Dairy J. 8 (1998) 171177.

[90] Horne D.S., Factors influencing acidinduced gelation of skim milk, in: Dickinson E., Miller R. (Eds.), Food Colloids, The Royal Society of Chemistry, Cambridge, 2001, pp. 345-351.

[91] Iametti S., Corredig M., Bonomi F., Characterization of casein isolated by ultracentrifugation from differently treated milks, Milchwissenschaft 48 (1993) 251254.

[92] Iametti S., De Gregori B., Vecchio G., Bonomi F., Modifications occur at differ- ent structural levels during the heat denaturation of $\beta$-lactoglobulin, Eur. J. Biochem. 237 (1996) 106-112.

[93] Imafidon G.I., Farkye N.Y., Composition of Cheddar cheese made from highheat treated milk, in: Emmons D.B. (Ed.), Cheese yield and factors affecting its control, IDF Seminar in Cork, International Dairy Federation, Bruxelles, Belgium, 1994, pp. 433-438.

[94] Jameson G.W., Lelièvre J., Effects of whey proteins on cheese characteristics, Bull. IDF 313 (1996) 3-8.

[95] Jang H.D., Swaisgood H.E., Disulfide bond formation between thermallly denatured $\beta$-lactoglobulin and $\kappa$-casein in casein micelles, J. Dairy Sci. 73 (1990) 900-904.

[96] Jean K., Renan M., Famelart M.-H., Guyomarc'h F., Structure and surface properties of the serum heat-induced aggregates isolated from heated skim milk, Int. Dairy J. 16 (2006) 303-315.

[97] Kaláb M., Allan-Wojtas P., Phipps-Todd B.E., Development of microstructure in set-style nonfat yoghurt - a review, Food Microstruct. 2 (1983) 51-66.

[98] Kaláb M., Emmons D.B., Sargant A.G., Milk gel structure. V. Microstructure of yoghurt as related to the heating of milk, Milchwissenschaft 31 (1976) 402-408.

[99] Keskin O., Gursoy A., Ma B., Nussinov R., Principles of protein-protein interactions: What are the preferred ways for proteins to interact?, Chem. Rev. 108 (2008) 12251244.

[100] Kinsella J.E., Whitehead D.M., Proteins in whey: chemical, physical and functional properties, Adv. Food Nutr. Res. 33 (1989) 343-438.

[101] Krasaekoopt W., Bhandari B., Deeth H., Yogurt from UHT milk: a review, Aust. J. Dairy Technol. 58 (2003) 26-29.

[102] Kudo S., The heat stability of milk: formation of soluble proteins and proteindepleted micelles at elevated temperatures, N. Z. J. Dairy Sci. Technol. 15 (1980) 255263.

[103] Lakemond C.M.M., van Vliet T., Acid milk gels: the gelation process as affected by preheating pH, Int. Dairy J. 18 (2008) 574584.

[104] Lakemond C.M.M., van Vliet T., Rheological properties of acid skim milk gels as affected by the spatial distribution of the structural elements and the 
interaction forces between them, Int. Dairy J. 18 (2008) 585-593.

[105] Law A.J.R., Banks J.M., Horne D.S., Leaver J., West I.G., Denaturation of the whey protein in heated milk and their incorporation into Cheddar cheese, Milchwissenschaft 49 (1994) 63-67.

[106] Law A.J.R., Leaver J., Effect of pH on the thermal denaturation of whey proteins in milk, J. Agric. Food Chem. 48 (2000) 672679.

[107] Lawrence R.C., Lelièvre J., Whey protein in cheese, in: Proceedings of the XXIIIth International Dairy Congress, Oct. 8-12th, 1990, Montreal, Vol. 3, 1991, pp. 18801888.

[108] Le Bon C., Nicolai T., Durand D., Growth and structures of aggregates of heat-induced $\beta$-lactoglobulin, Int. J. Food Sci. Technol. 34 (1999) 451-466.

[109] Le Bon C., Nicolai T., Durand D., Kinetics of aggregation and gelation of globular proteins after heat-induced denaturation, Macromolecules 32 (1999) 6120-6127.

[110] Lee W.-J., Lucey J.A., Rheological properties, whey separation, and microstructure in set-style yogurt: effects of heating temperature and incubation temperature, J. Text. Stud. 34 (2004) 515-536.

[111] Le Feunteun S., Mariette F., Impact of casein gel microstructure on self-diffusion coefficient of molecular probes measured by $\mathrm{H}^{1}$ PFG-NMR, J. Agric. Food Chem. 55 (2007) 10764-10772.

[112] Le Graët Y., Gaucheron F., pH-induced solubilization of minerals from casein micelles: influence of casein concentration and ionic strength, J. Dairy Res. 66 (1999) 215-224.

[113] Livney Y.D., Corredig M., Dalgleish D.G., Influence of thermal processing on the properties of dairy colloids, Curr. Opinion Colloids Interface Sci. 8 (2003) 359-364.

[114] Livney Y.D., Dalgleish D.G., Specificity of disulfide bond formation during thermal aggregation in solutions of $\beta$-lactoglobulin $\mathrm{B}$ and $\kappa$-casein A, J. Agric. Food Chem. 52 (2004) 5527-5532.

[115] Livney Y.D., Verespej E., Dalgleish D.G., Steric effects governing disulfide bond interchange during thermal aggregation in solutions of $\beta$-lactoglobulin $B$ and $\alpha$-lactalbumin, J. Agric. Food Chem. 51 (2003) 8098-8106.

[116] Lowe E.K., Anema S.K., Bienvenue A., Boland M.J., Creamer L.K., Jiménez-Flores
R., Heat-induced redistribution of disulfide bonds in milk proteins. 2. Disulfide bonding patterns between bovine $\beta$-lactoglobulin and $\kappa$-casein, J. Agric. Food Chem. 52 (2004) 7669-7680.

[117] Lucey J.A., Formation and physical properties of milk protein gels, J. Dairy Sci. 85 (2002) 281-294.

[118] Lucey J.A., Cultured dairy products: an overview of their gelation and texture properties, Int. J. Dairy Technol. 57 (2004) 77-84.

[119] Lucey J.A., Singh H., Formation and physical properties of acid milk gels: a review, Food Res. Int. 30 (1998) 529-542.

[120] Lucey J.A., Tamehana M., Singh H., Munro P.A., Effect of interactions between denatured whey proteins and casein micelles on the formation and rheological properties of acid milk gels, J. Dairy Res. 65 (1998) 555-567.

[121] Lucey J.A., Tamehana M., Singh H., Munro P.A., Rheological properties of milk gels formed by a combination of rennet and glucono- $\delta$-lactone, J. Dairy Res. 67 (2000) 415-427.

[122] Lucey J.A., Tamehana M., Singh H., Munro P.A., Effect of heat treatment on the physical properties of milk gels made with both rennet and acid, Int. Dairy J. 11 (2001) 559565.

[123] Lucey J.A., Teo C.T., Munro P.A., Singh H., Rheological properties at small (dynamic) and large (yield) deformations of acid gels made from heated milk, J. Dairy Res. 64 (1997) 591-600.

[124] Lucey J.A., Teo C.T., Munro P.A., Singh H., Microstructure, permeability and appearance of acid gels made from heated skim milk, Food Hydrocoll. 12 (1998) 159-165.

[125] Mahmoudi N., Mehalebi S., Nicolai T., Durand D., Riaublanc A., Light scattering study of the structure of aggregates and gels formed by heat-denatured whey protein isolate and $\beta$-lactoglobulin and neutral pH, J. Agric. Food Chem. 55 (2007) 3104-3111.

[126] Marshall R.J., Increasing cheese yields by high heat-treatment of milk, J. Dairy Res. 53 (1986) 313-322.

[127] Matsudomi N., Kanda Y., Yoshika Y., Moriwaki H., Ability of $\alpha_{\mathrm{s}}$-casein to suppress the heat aggregation of ovotransferrin, J. Agric. Food Chem. 52 (2004) 48824886. 
[128] Mc Kenzie G.H., Norton R.S., Sawyer W.H., Heat-induced interaction of $\beta$-lactoglobulin and $\kappa$-casein, J. Dairy Res. 38 (1971) 343-351.

[129] McMahon D.J., Age-gelation of UHT milk: changes that occur during storage, their effect on shelf life and the mechanism by which age-gelation occurs, in: Heat treatments and alternative methods, Proceedings of the IDF Symposium, Vienna, September 1995, 1996, pp. 315-326.

[130] Ménard O., Camier B., Guyomarc'h F., Effect of heat-treatment at alkaline $\mathrm{pH}$ on rennet coagulation properties of skim milk, Lait 85 (2005) 515-526.

[131] Mollé D., Jean K., Guyomarc'h F., Chymosin sensitivity of the heat-induced serum protein aggregates isolated from skim milk, Int. Dairy J. 16 (2006) 14351441 .

[132] Mottar J., Bassier A., Joniau M., Baert J., Effect of heat-induced association of whey protein and casein micelles on yoghurt texture, J. Dairy Sci. 72 (1989) 2247-2256.

[133] Noh B., Creamer L.K., Richardson T., Thermally induced complex formation in an artificial milk system, J. Agric. Food Chem. 37 (1989) 1395-1400.

[134] Noh B., Richarson T., Incorporation of radiolabeled whey proteins into casein micelles by heat processing, J. Dairy Sci. 72 (1989) 1724-1731.

[135] Noh B., Richardson T., Creamer L.K., Radiolabelling study of the heat-induced interactions between $\alpha$-lactalbumin, $\beta$-lactoglobulin and $\kappa$-casein in milk and buffer solutions, J. Food Sci. 54 (1989) 889-893.

[136] O'Connell J.E., Fox P.F., Effect of $\beta$-lactoglobulin and precipitation of calcium phosphate on the thermal coagulation of milk, J. Dairy Res. 68 (2001) 81-94.

[137] O'Kennedy B.T., Kelly P.M., Evaluation of milk protein interactions during acid gelation using a simulated yoghurt model, Milchwissenschaft 55 (2000) 187-190.

[138] O'Kennedy B.T., Mounsey J.S., Control of heat-induced aggregation of whey proteins using casein, J. Agric. Food Chem. 54 (2006) 5637-5642.

[139] Oh S., Richardson T., Heat-induced interactions of bovine serum albumin and immunoglobulin, J. Dairy Sci. 74 (1991) 1786-1790.

[140] Oldfield D.J., Singh H., Taylor M.W., Association of $\beta$-lactoglobulin and $\alpha$-lactalbumin with the casein micelles in skim milk heated in an ultra-high temperature plant, Int. Dairy J. 8 (1998) $765-770$.

[141] Oldfield D.J., Singh H., Taylor M.W., Pearce K.N., Kinetics of denaturation and aggregation of whey proteins in skim milk heated in an ultra-high temperature (UHT) pilot plant, Int. Dairy J. 8 (1998) 311-318.

[142] Oldfield D.J., Singh H., Taylor M.W., Pearce K.N., Heat-induced interactions of $\beta$-lactoglobulin and $\alpha$-lactalbumin with the casein micelle in $\mathrm{pH}$-adjusted skim milk, Int. Dairy J. 10 (2000) 509-518.

[143] Ozcan-Yilsay T., Lee W.-J., Horne D.S., Lucey J.A., Effect of trisodium citrate on rheological and physical properties and microstructure of yogurt, J. Dairy Sci. 90 (2007) 1644-1652

[144] Park S.-Y., Nakamura K., Niki R., Effects of $\beta$-lactoglobulin on the rheological properties of casein micelle rennet gels, J. Dairy Sci. 79 (1996) 2137-2145.

[145] Parker E.A., Donato L., Dalgleish D.G., Effects of added sodium caseinate on the formation of particles in heated skim milk, J. Agric. Food Chem. 53 (2005) 82658272.

[146] Parnell-Clunies E., Kakuda Y., Deman J.M., Influence of heat treatment of milk on the flow properties of yoghurt, J. Food Sci. 51 (1986) 1459-1462.

[147] Parnell-Clunies E., Kakuda Y., Smith A.K., Microstructure of yogurt as affected by heat-treatment of milk, Milchwissenschaft 42 (1987) 413-417.

[148] Parris N., Anema S.G., Singh H., Creamer L.K., Aggregation of whey proteins in heated sweet whey, J. Agric. Food Chem. 41 (1993) 460-464.

[149] Parris N., Hollar C.M., Hsieh A., Cockley K.D., Thermal stability of whey protein concentrate mixtures: aggregate formation, J. Dairy Sci. 30 (1997) 18-28.

[150] Patel H.A., Singh H., Anema S.G., Creamer L.K., Effects of heat and high hydrostatic pressure treatments on disulfide bonding interchanges among the proteins in skim milk, J. Agric. Food Chem. 54 (2006) 3409-3420.

[151] Patocka G., Jelen P., Kalab M., Thermostability of skim milk with modified casein/whey protein content, Int. Dairy J. 3 (1993) 35-48.

[152] Pearse M.J., Linklater P.M., Hall R.J., McKinlay A., Effects of heat-induced 
interaction between $\beta$-lactoglobulin and $\kappa$-casein on syneresis, J. Dairy Res. 52 (1985) 159-165.

[153] Plock J., Spiegel T., Kessler H.-G., Influence of the dry matter on the denaturation kinetics of whey proteins in concentrated sweet whey, Milchwissenschaft 53 (1998) 327-331.

[154] Plock J., Spiegel T., Kessler H.-G., Influence of the lactose concentration on the denaturation kinetics of whey proteins in concentrated sweet whey, Milchwissenschaft 53 (1998) 389-393.

[155] Pouliot Y., Boulet M., Paquin P., Observations on the heat induced salt balance changes in milk. I: Effect of heating time between 4 and $90{ }^{\circ} \mathrm{C}$, J. Dairy Res. 56 (1989) 185-192.

[156] Prabakaran S., Damodaran S., Thermal unfolding of $\beta$-lactoglobulin: characterization of initial unfolding events responsible for heat-induced aggregation, J. Agric. Food Chem. 45 (1997) 4303-4308.

[157] Puvanenthiran A., Williams R.P.W., Augustin M.A., Structure and visco-elastic properties of set yoghurt with altered casein to whey protein ratios, Int. Dairy J. 12 (2002) 383-391.

[158] Reddy I.M., Kinsella J.E., Interaction of $\beta$-lactoglobulin with $\kappa$-casein in micelles as assessed by chymosin hydrolysis: effects of temperature, heating time, $\beta$-lactoglobulin concentration, and $\mathrm{pH}$, J. Agric. Food Chem. 38 (1990) 50-58.

[159] Relkin P., Thermal unfolding of $\beta$-lactoglobulin, $\quad \alpha$-lactalbumin, and bovine serum albumin. A thermodynamic approach, Crit. Rev. Food Sci. Nut. 36 (1996) 565-601.

[160] Relkin P., Reversibility of heat-induced conformational changes and surface exposed hydrophobic clusters of $\beta$-lactoglobulin: their role in heat-induced sol-gel transition, Int. J. Biol. Macromol. 22 (1998) 59-66.

[161] Renan M., Guyomarc'h F., Chatriot M., Gamerre V., Famelart M.-H., Limited enzymatic treatment of skim milk using chymosin affects the micelle/serum distribution of the heat-induced whey protein/ $\kappa$-casein aggregates, J. Agric. Food Chem. 55 (2007) 6736-6745.

[162] Renan M., Mekmene O., Famelart M.-H., Guyomarc'h F., Arnoult-Delest V., Pâquet D., Brulé G., pH-Dependent behaviour of soluble protein aggregates formed during heat-treatment of milk at $\mathrm{pH} 6.5$ or 7.2 , J. Dairy Res. 73 (2006) 79-86.

[163] Ribadeau-Dumas B., Garnier J., Structure of the casein micelle. The accessibility of the subunits to various reagents, J. Dairy Res. 37 (1970) 269-278.

[164] Rodriguez del Angel C., Dalgleish D.G., Structures and some properties of soluble protein complexes formed by the heating of reconstituted skim milk powder, Food Res. Int. 39 (2006) 472-479.

[165] Roefs S.P.F.M., de Kruif K.G., A model for the denaturation and aggregation of $\beta$-lactoglobulin, Eur. J. Biochem. 226 (1994) 883-889.

[166] Roesch R.R., Corredig M., Study of the effect of soy proteins on the acid-induced gelation of casein micelles, J. Agric. Food Chem. 54 (2006) 8236-8243.

[167] Sawyer W.H., Complex between $\beta$-lactoglobulin and $\kappa$-casein. A review, J. Dairy Sci. 52 (1969) 1347-1355.

[168] Schmidt D.G., Association of caseins and casein micelle structure, in: Fox P.F. (Ed.), Development in Dairy Chemistry, Volume 1, Proteins, Applied Science Publishers, London, UK, 1982, pp. 61-86.

[169] Schorsch C., Wilkins D.K., Jones M.G., Norton I.T., Gelation of casein-whey mixtures: effects of heating whey proteins alone or in the presence of casein micelles, J. Dairy Res. 68 (2001) 471-481.

[170] Singh H., Heat-induced changes in milk, including interactions with whey proteins, in: Fox P.F. (Ed.), Heat-induced changes in milk, Special issue 9501, International Dairy Federation, Bruxelles, Belgium, 1995, pp. 86-104.

[171] Singh H., Creamer L.K., Aggregation and dissociation of milk protein complexes in heated reconstituted concentrated skim milk, J. Food Sci. 56 (1991) 238-246.

[172] Singh H., Fox P.F., Heat stability of milk: $\mathrm{pH}$-dependent dissociation of micellar $\kappa$-casein on heating milk at ultra-high temperatures, J. Dairy Res. 52 (1985) 529-538.

[173] Singh H., Fox P.F., Heat stability of milk: further studies on the $\mathrm{pH}$-dependent dissociation of micellar $\kappa$-casein, J. Dairy Res. 53 (1986) 237-248.

[174] Singh H., Fox P.F., Heat stability of milk: role of $\beta$-lactoglobulin in the $\mathrm{pH}$-dependent dissociation of micellar $\kappa$-casein, J. Dairy Res. 54 (1987) 509-521. 
[175] Singh H., Fox P.F., Heat stability of milk: influence of colloidal and soluble salts and protein modification on the $\mathrm{pH}$-dependent dissociation of micellar $\kappa$-casein, J. Dairy Res. 54 (1987) 523-534.

[176] Smits P., van Brouwershaven J.V.H., Heatinduced association of $\beta$-lactoglobulin and casein micelles, J. Dairy Res. 47 (1980) 313-325.

[177] Sodini I., Remeuf F., Haddad S., Corrieu G., The relative effect of milk base, starter and process on yoghurt texture: a review, Crit. Rev. Food Sci. Nut. 44 (2004) 113-137.

[178] Surroca Y., Haverkamp J., Heck A.J.R., Towards the understanding of molecular mechanisms in the early stages of heatinduced aggregation of $\beta$-lactoglobulin $A B$, J. Chromatogr. A 970 (2002) 275-285.

[179] Tolkach A., Kulozik U., Reaction kinetic pathway of reversible and irreversible thermal denaturation of $\beta$-lactoglobulin, Lait 87 (2007) 301-315.

[180] Tran-Le T., El-Bakry M., Neirynck N., Bogus M., Dinh Hoa H., van der Meeren P., Hydrophilic lecithins protect milk proteins against heat-induced aggregation, Colloids Surfaces B: Biointerfaces 60 (2007) 167173.

[181] Unterhaslberger G., Schmitt C., Sanchez C., Appolonia-Nouzille C., Raemy A., Heat-denaturation and aggregation of $\beta$-lactoglobulin enriched WPI in the presence of arginine $\mathrm{HCl}, \mathrm{NaCl}$ and guanidinium $\mathrm{HCl}$ at $\mathrm{pH} 4.0$ and 7.0, Food Hydrocoll. 20 (2006) 1006-1019.

[182] Unterhaslberger G., Schmitt C., ShojaeiRami S., Sanchez C., Beta-lactoglobulin aggregates from heating with charged cosolutes: formation, characterization and foaming, in: Dickinson E., Leser M. (Eds.), Food Colloids: Self assembly and material science, The Royal Society of Chemistry, Cambridge, 2007, pp. 175-192.

[183] Van Hooydonk A.C.M., de Koster P.G., Boerrigter I.J., The renneting properties of heated milk, Neth. Milk Dairy J. 41 (1987) 3-18.

[184] Van Kemenade M.J.J.M., de Bruyn P.L., The influence of casein on the precipitation of brushite and octacalcium phosphate, Colloids Surfaces 36 (1989) 359-368.
[185] Van Vliet T., Roefs S.P.F.M., Zoon P., Walstra P., Rheological properties of casein gels, J. Dairy Res. 56 (1989) 529-534.

[186] Vasbinder A.J., Alting A.C., de Kruif K.G., Quantification of heat-induced casein-whey protein interactions in milk and its relation to gelation kinetics, Colloids Surfaces B: Biointerfaces 31 (2003) 115-123.

[187] Vasbinder A.J., de Kruif C.G., Casein-whey protein interactions in heated milk: the influence of pH, Int. Dairy J. 13 (2003) 669677.

[188] Vasbinder A.J., Rollema H.S., De Kruif C.G., Impaired rennetability of heated milk; study of enzymatic hydrolysis and gelation kinetics, J. Dairy Sci. 86 (2003) 15481555.

[189] Vasbinder A.J., van de Velde F., de Kruif C.G., Gelation of casein-whey protein mixtures, J. Dairy Sci. 87 (2004) 1167-1176.

[190] Vasbinder A.J., van Mil P.J.J.M., Bot A., de Kruif C.G., Acid-induced gelation of heat-treated milk studied by diffusing wave spectroscopy, Colloids Surfaces B 21 (2001) 245-250.

[191] Verheul M., Roefs S.P.F.M., de Kruif K.G., Kinetics of heat-induced aggregation of $\beta$-lactoglobulin, J. Agric. Food Chem. 46 (1998) 896-903.

[192] Walstra P., On the stability of casein micelles, J. Dairy Sci. 73 (1990) 1965-1979.

[193] Walstra P., Jenness R., Proteins, in: Walstra P., Jenness R. (Eds.), Dairy Chemistry and Physics, Wiley and Sons, New York, USA, 1984, pp. 98-122.

[194] Zhang X., Fu X., Zhang H., Liu C., Wangwang J., Chang Z., Chaperone-like activity of $\beta$-casein, Int. J. Biochem. Cell Biol. 37 (2005) 1232-1240.

[195] Zittle C.A., Thompson M.P., Custer J.H., Cerbulis J., $\kappa$-casein- $\beta$-lactoglobulin interaction in solution when heated, J. Dairy Sci. 45 (1962) 807-810.

[196] Zoon P., Incorporation of whey proteins into Dutch-type cheese, in: Emmons D.B. (Ed.), Cheese yield and factors affecting its control, IDF Seminar in Cork, International Dairy Federation, Bruxelles, Belgium, 1994, pp. 402-408. 